\title{
The North Pyrenean Frontal Thrust: structure, timing and late fluid circulation inferred from seismic and thermal-geochemical analyses of well data
}

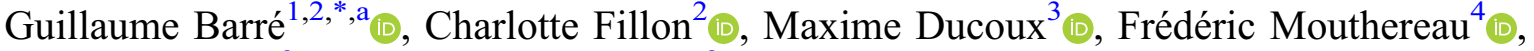 \\ Eric C. Gaucher ${ }^{2} \odot$ and Sylvain Calassou ${ }^{2}$ \\ ${ }^{1}$ Université de Pau et Pays de l'Adour, E2S UPPA, CNRS, TOTAL, LFCR, UMR 5150, 64000 Pau, France \\ 2 TOTAL EP R\&D, CSTJF, Avenue Larribau, 64018 Pau, France \\ ${ }^{3}$ M\&U SAS, 3 Rue des Abattoirs, 38120 Saint-Égrève, France \\ ${ }^{4}$ Géosciences Environnement Toulouse (GET), Université de Toulouse, UPS, Univ. Paul Sabatier, CNRS, IRD, CNES, 14 av. Edouard \\ Belin, F-31400 Toulouse, France
}

Received: 8 April 2021 / Accepted: 5 October 2021 / Publishing online: 2 November 2021

\begin{abstract}
During orogenesis, large-scale thrusts as orogenic fronts can act as conduits and/or barriers for fluid flow. Unravelling the timing and modes of tectonic activation of large-scale faults is crucial to understanding the relationship between fluid flow and deformation. The North Pyrenean Frontal Thrust (NPFT) corresponds to a major basement-involved thrust responsible for the northward overthrust of the pre-orogenic sediments on top of the Aquitaine Foreland Basin. This study questions the timing of activation of this thrust, its geometry, the nature of the last fluids, which circulated there, and its role on the circulation of fluids. The structural study confronted to published thermochronology data led to determine the timing of the two tectonic activations during the NPFT compression phase and to relate them to the fluid circulations. We constrain the first activation at Campanian times and link it to the leak of the deep gas reservoir present in depth, as the NPFT acted as a conduit. Then the NPFT acted as a barrier, probably due to the breccia consolidation during the Paleocene quiescence period. Finally, the Eocene-Oligocene reactivation led to fluid circulation of high salinity fluids from the Triassic evaporites leaching. This latter event is associated with a fracturing event and the late generation of calcite veins studied here. This is the first study in the Pyrenees directly applied to the NPFT which uses the association between fluid inclusions study, seismic and thermochronological data. It highlights that the NPFT may be an important structure responsible of the leakage of deep hydrocarbons reservoirs. It also shows the importance of the determination of the activation steps of large-scale faults to decipher the origin of fluid circulations in space and time.
\end{abstract}

Keywords: Pyrenees / North Pyrenean Frontal Thrust / fluid inclusions / thermochronology / stable isotopes / evaporites

\begin{abstract}
Résumé - Le chevauchement frontal Nord Pyrénéen : structure, timing et circulation de fluide tardif déduits d'analyses sismiques et thermo-géochimiques de données de puits. Au cours d'une orogenèse, les chevauchements majeurs en tant que fronts orogéniques peuvent agir comme conduits et/ou barrières pour la circulation de fluides. Il est essentiel de comprendre la chronologie et le mode d'activation de telles failles à grande échelle, pour comprendre la relation entre les circulations fluides et la déformation. Le Chevauchement Frontal Nord Pyrénéen (CFNP) correspond à un chevauchement majeur ancré dans le socle et responsable du chevauchement vers le nord des sédiments pré-orogéniques au sommet du Bassin d'avantpays Aquitaine. Cette étude interroge le timing d'activation de ce chevauchement, sa géométrie, la nature des derniers fluides qui y ont circulé et son rôle dans la mise en circulation de ces fluides. L'étude structurale confrontée à des données de thermochronologie déjà publiées, a conduit à déterminer la chronologie des
\end{abstract}

\footnotetext{
*Corresponding author: guillaume.barre.2@ulaval.ca

apresent address: Département de géologie et génie géologique, Centre E4M, Université Laval, Québec, Canada.
} 
deux activations tectoniques de la phase de compression du CFNP et à les relier aux circulations fluides. Nous contraignons la première activation au Campanien et a probablement conduit à la fuite du réservoir de gaz présent en profondeur, le CFNP jouant le rôle de conduit. Ensuite, il a agi comme une barrière, probablement en raison de la consolidation de la brèche pendant la période de quiescence du Paléocène. Enfin, la réactivation Eocène-Oligocène a conduit à une circulation de fluides très salés issus du lessivage des évaporites du Trias. Ce dernier événement est associé à un événement de fracturation et à la génération tardive des veines de calcite étudiées ici. Il s'agit de la première étude dans les Pyrénées directement appliquée au NPFT qui utilise une association entre étude des inclusions fluides et données sismiques et thermochronologiques. Elle met en évidence que le NPFT peut être une structure importante responsable de la fuite des réservoirs d'hydrocarbures profonds. Elle montre également l'importance de la détermination des étapes d'activation des chevauchements de grande échelle pour déterminer l'origine des circulations fluides dans l'espace et le temps.

Mots clés : Pyrénées / chevauchement frontal Nord Pyrénéen / inclusions fluides / thermochronologie / isotopes stables / évaporites

\section{Introduction}

Large-scale faults at orogenic fronts are privileged places to study the relationships between long-term deformation processes with short-term episodic fluid circulations. Fluid/ rock interactions studies in faults zones were originally driven by industrial needs to understand the role and timing of the fluid circulations in these faults at the origin of oil and gas and ore deposits (e.g., Travé et al., 1997, 1998; Boles et al., 2004; Eichhubl et al., 2009; Weis et al., 2012; Grare et al., 2018). Fluid flow associated to active faults is governed by different mechanisms such as fault-valve action, seismic pumping, anisotropic permeability, or hydraulic fracturing by increasing pore pressure (e.g., Sibson, 1981, 2000; McCaig, 1988; Magee and Zoback, 1993; Bense and Person, 2006). Foreland thrusts are known to usually act as conduits for fluids (Travé et al., 2000; Cruset et al., 2018; Smeraglia et al., 2020) driving circulation of different types of fluids dependent on their tectonic history and sources (e.g., Travé et al., 2007; Lacroix et al., 2014). Only recently, the increasing ability of geothermochronometric techniques to resolve the timing of complex fluid flow events open the way to significantly improve our knowledge of rock-fluids interactions (Louis et al., 2019, Milesi et al., 2019, 2020). Source, nature and timing of the fluid circulations in the central part of the South Pyrenean Zone are well documented for Cenozoic synorogenic deformation phases (e.g., Rye and Bradbury, 1988; Travé et al., 2000; Lacroix et al., 2014; Beaudoin et al., 2015; Crognier et al., 2018; Cruset et al., 2018). In the North Pyrenean Zone and Aquitaine Basin most studies dealing with fluid circulations have focused on the Mesozoic syn-rift history (Salardon et al., 2017; Corre et al., 2018; Quesnel et al., 2019; Renard et al., 2019; Elias-Bahnan et al., 2020; Motte et al., 2021; Cathelineau et al., 2021), the syn-orogenic imprint remaining poorly constrained. One of the main syn-orogenic faults carrying fluids in the north of Pyrenees is the North Pyrenean Frontal Thrust(NPFT; Connan and Lacrampe-Couloume, 1993) which separate the Aquitaine Foreland Basin from the North Pyrenean Zone (NPZ; Fig. 1).

The NPFT is a large basement-involved structure responsible for the northward overthrust bringing the Early Cretaceous syn-rift successions (Barremian-Albian) on top of the late Cretaceous to Paleogene deposits of the Aquitaine
Basin. While studies on the tectonic evolution of the NPFT have been carried out in the Central and Eastern Pyrenees (Mattauer and Proust, 1962; Charrière and Durand-Delga, 2004; Ford et al., 2016; Labaume and Teixell, 2020), the arguments used to constrain its activity to the west remain very scarce as the western fault trace is buried below a thin layer of Miocene post-orogenic sediments. The role and timing of the NPFT in controlling fluid circulation has not yet been demonstrated.

In this study, we couple new geochemical and interpretation of seismic reflection lines with recently published thermochronological analyses to determine the timing of thrust activity and the nature and origin of the late fluid circulations in the NPFT. The fluid circulation model is built in accordance with previous more detailed geochemical studies. This contribution integrates results from both Fluids and Orogen R\&D Total projects (please refer to the Website for more information on these projects: https://convergentmargins.com/) to document fluid-rock interactions associated with large-scale convergent complex structures.

\section{Main deformation phases in the Pyrenean orogen}

The Pyrenees are an alpine-type mountain belt formed between the Santonian and the Miocene as a result of the convergence between Iberia and Europe. Collision involves a Variscan basement and a Mesozoic sedimentary cover that underwent Early Cretaceous rifting. Evidence for the Early Cretaceous rifting are best preserved in the North Pyrenean Zone (NPZ; Fig. 1), where the crustal thinning led to hyperextension and mantle exhumation (e.g., Fabriès et al., 1991, 1998; Lagabrielle and Bodinier, 2008; Jammes et al., 2009; Lagabrielle et al., 2010; Clerc et al., 2012, 2013; Masini et al., 2014; Tugend et al., 2014). The peculiar thermal evolution of the Pyrenean rifting is well documented and has revealed widespread HT-LP metamorphism (Ravier, 1959; Azambre and Rossy, 1976; Bernus-Maury, 1984; Dauteuil and Ricou, 1989; Golberg and Leyreloup, 1990; Clerc and Lagabrielle, 2014; Clerc et al., 2015; Lescoutre et al., 2019; Ducoux et al., 2019, 2021b), and the establishment of high geothermal gradient (up to $80^{\circ} \mathrm{C} / \mathrm{km}$; Vacherat et al., 2014; 


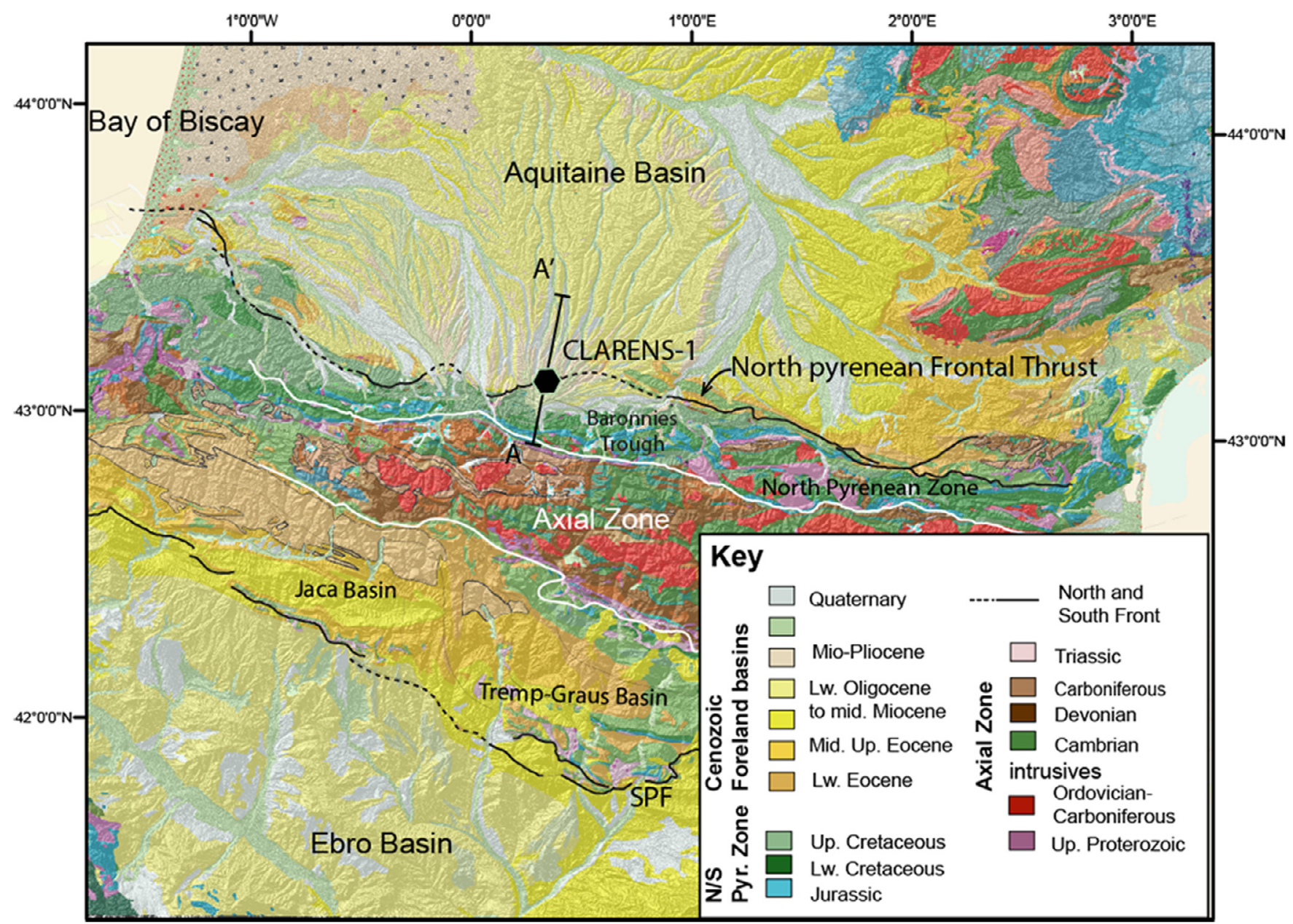

Fig. 1. Geological map of the Pyrenean Range with location of the main features discussed in this study. AA' is the section detailed in Figure 3.

Renard et al., 2019) in Early Cretaceous sediments of the Mauléon Basin, in the Western Pyrenees.

The onset of Iberia/Europe convergence is documented by the oldest sea-floor spreading magnetic anomalies in the Atlantic Ocean dated to the Santonian (e.g., Roest and Srivastava, 1991; Olivet, 1996; Rosenbaum et al., 2002; Sibuet et al., 2004; Macchiavelli et al., 2017) and geological evidence in the Pyrenees of a late Santonian unconformity and deposition of clastic sediments (Garrido et al., 1972; Muñoz, 1992; Vergés et al., 1995; Teixell, 1998; Vergés and García Senz, 2001; García Senz, 2002; McClay et al., 2004; Mouthereau et al., 2014; Labaume and Teixell, 2020). This early convergence stage is marked by the underthrusting of the exhumed mantle and hyperextended rift domain (Mouthereau et al., 2014; Ford et al., 2016; Teixell et al., 2016; Gómez-Romeu et al., 2019). As deformation propagated southward by the accretion of more proximal domains of the Iberian margin, the inversion of former rift structures such as the Boixols fault occurred, driving deposition of CampanianMaastrichtian flysch (see synthesis in Martín-Chivelet et al., 2019). This early orogenic phase is supported by substantial evidence arguing for an early phase of cooling at about $70 \mathrm{Ma}$ based on low-temperature thermochronology (e.g., Whitchurch et al., 2011; Beamud et al., 2011; Mouthereau et al., 2014; Ternois et al., 2019; Waldner et al., 2021).
Farther west, marine geophysical constraints further document Santonian-Campanian heterogeneous reactivation of the northern Bay of Biscay (Thinon et al., 2001). This is also suggested in the Basque-Cantabrian Basin by the transition from calcareous to siliciclastic flyschs in the early Campanian times. Farther north, subsidence analyses and flexure modelling reveal that the onset of foreland deflection of the European plate occurred in the late Cretaceous in response to incipient orogenic loading (Vergés et al., 2002; Ford et al., 2016; Angrand et al., 2018).

The mature collisional stage marked by widespread orogenic exhumation in the Pyrenees occurred from $\sim 50 \mathrm{Ma}$ to $\sim 20 \mathrm{Ma}$ (Muñoz, 1992; Mouthereau et al., 2014 and references therein) suggests an onset of accretion of necking domains as argued by modelling (Jourdon et al., 2019). This interval defines a period of wedge widening that is reflected in the southern fold-and-thrust belt by thin-skinned deformation accommodated in the Triassic evaporitic level (e.g. Tremp-Graus Basin, see Fig. 1). In the North Pyrenean Zone, however, thick-skinned or basement-involved inversion is the dominant mode of deformation. This is associated with less mechanical decoupling between the basement and suprasalt sedimentary units that indicate comparatively less shortening on the retro-wedge side of the orogen (Jourdon et al., 2019). In the Axial Zone, deformation is characterized 
by crustal nappe stacking. The positive feedback between tectonics and climate resulted in intense exhumation of the Axial Zone between $\sim 40 \mathrm{Ma}$ and $\sim 30 \mathrm{Ma}$ at rates up to $2 \mathrm{~km} / \mathrm{Myr}$ (Fitzgerald et al., 1999; Fillon and van der Beek, 2012). Contraction and flexural subsidence associated with topographic loading appear to have ceased slightly earlier $(\sim 23 \mathrm{Ma}$; Rocher et al., 2000; Ortiz et al., 2020) in the northern retro-foreland than in the southern pro-foreland ( $18 \mathrm{Ma}$, Oliva-Urcia et al., 2019).

\section{Borehole description}

Throughout this study, we use the Clarens-1 borehole (CLS-1) which was drilled in the 60's at the early stages of hydrocarbon exploration in the Aquitaine Basin by Elf and is now part of the patrimonial TOTAL dataset. This borehole is located in the retro-foreland of the Pyrenean belt, at the apex of the Lannemezan plateau. The borehole penetrates the Cenomanian series made of alternation of marls with a few sandstone beds from $200 \mathrm{~m}$ to $\sim 1000 \mathrm{~m}$ depth, then a disturbed $\sim 500 \mathrm{~m}$ thick zone consisting of polygenic breccias into the Cenomanian marls, interpreted as the North Pyrenean Frontal Thrust(NPFT) damage zone. Finally, Maastrichtian and Campanian rocks have been drilled between $\sim 1500 \mathrm{~m}$ to $3500 \mathrm{~m}$ (Fig. 2). Present-day temperature measured in the Clarens-1 borehole indicates a value of $65^{\circ} \mathrm{C}$ at $2698 \mathrm{~m}$ (geothermal gradient of $24^{\circ} \mathrm{C} / \mathrm{km}$ ), consistent with the temperatures measured in other boreholes nearby (TOTAL internal data).

\section{Methodology}

\subsection{Seismic interpretation}

The structure of the NPFT is inferred from seismic reflection data and boreholes information available from the TOTAL patrimonial dataset. In order to detail the architecture of the NPFT and the adjacent Aquitaine Basin, a new geological cross-section is proposed based on the interpretation of a N-S seismic profile (85SAV2, courtesy of Total SE) and 7 wells (Lannemezan-1 \& 2, Clarens-1, 2 \& 102, Monlong-1 and Recurt-1) (Fig. 3).

\subsection{Petrography}

Rock samples from the breccia zones at 1000, 1487 and $1489 \mathrm{~m}$ in the Cenomanian formation, were collected to determine the different generations of cements and veins. Observations were made under an optical microscope and systematically supplemented by cathodoluminescence petrography performed with a NewTec Scientific cathodyne $(10-12 \mathrm{kV}$ and $100 \mathrm{~mA})$ coupled to a Nikon eclipse $80 \mathrm{i}$ microscope and a digital iDS camera.

\subsection{Microthermometric analysis}

Samples for microthermometry analysis were taken from the Clarens-1 borehole. First, we conducted macroscopic observations over the entire available core of the Clarens-1 borehole to characterize the structure and composition of late calcite veins (Cal3) used for fluid inclusions study (see Sect. 5.1 for the relative timing of the different generations). Due to limited sampling possibilities, only veins in the fault zone at $1000 \mathrm{~m}$ and $1487 \mathrm{~m}$ depth were used for fluid inclusions analysis. The hostrock is a polygenic breccia within the Cenomanian marls crosscut by calcite veins where fluid inclusions were analyzed (Figs. 4A and 4B). A total of 42 fluid inclusions were studied on double polished $150 \mu \mathrm{m}$-thick sections from the calcite veins. Microthermometric measurements were performed by ${ }^{\circledR} \mathrm{HES}$ Expertise Services, on a Linkam MDS 600 heating-cooling stage connected to a Sony Exwave HAD3 color video camera mounted on an Olympus BX 51 microscope at GeoRessources, Vandoeuvre-lès-Nancy. The microthermometric stage was thermally calibrated using $\mathrm{CO}_{2}$ synthetic fluid inclusions standards for $T_{\mathrm{m}\left(\mathrm{CO}_{2}\right)}$ (melting temperature of $\left.\mathrm{CO}_{2}\right), \mathrm{H}_{2} \mathrm{O}$ synthetic fluid inclusions standards for $T_{\mathrm{m} \text { (ice) (melting }}$ temperature of ice), and cross-calibrated natural alpine fluid inclusions ("home" standard) for $T_{\mathrm{h}}$ (homogenization temperature). The accuracy of measurements is estimated at $\pm 0.2^{\circ} \mathrm{C}$ for $T_{\text {m(ice) }}$ and $\pm 0.5^{\circ} \mathrm{C}$ for $T_{\mathrm{h}}$. In order to detect the presence of oilrich fluid inclusions, epi-UV fluorescence observations were conducted using a Zeiss AxioImager.A1m microscope with an excitation filter centered at $365 \pm 5 \mathrm{~nm}$ and an emission filter long pass around $400 \mathrm{~nm}$.

\subsection{Vitrinite reflectance analysis}

Only 4 organic matter-rich samples suitable for reflected light microscopy were found on the Clarens- 1 core. They were crushed between 1 to $2 \mathrm{~mm}$ for observation of the organic facies and for estimation of the fluorescence intensity of the groundmass. A concentrate of organic matter using heavy liquid was used for random measurements. Random reflectance measurements were conducted using a LEICA DM4P or DM4500P microscopes, with objectives of $\mathrm{x} 20$ and $\mathrm{x} 50$. Calibration was made with three standards method: Saphir $(0.586 \%)$, Glass $(1.25 \%)$ for low maturity, Glass $(1.25 \%)$ and Zirkonia (3.115\%) for medium maturity, and Zirkonia $(3.115 \%$ to $7.32 \%$ ) for high maturity.

\section{Results}

\subsection{Structure of the North Pyrenean Frontal Thrust}

The cross-section we investigate stretches between the Baronnies Trough to the south and the Aquitaine Basin to the north (Fig. 3). The Baronnies Trough corresponds to a syn-rift basin that developed over a hyperthinned crust and an exhumed mantle domain (e.g., Espurt et al., 2019). As determined in the Lannemezan-1 well, the northern part of Baronnies Trough located on the hanging wall of the NPFT is filled by Albo-Cenomanian syn-rift successions which sit on the Upper Triassic evaporites (Fig. 3). It is noteworthy the lack of the pre-rift sequence in the northern part of the Baronnies Trough. Indeed, this was not recognized in the Lannemezan$1 \& 2$ wells where the syn-rift deposits overlay the Upper Triassic evaporites. Below this non-isopachous evaporitic sequence, the top of the basement can be highlighted by highamplitude reflectors (Fig. 3). Large accumulations of saltbearing rocks $(>1.5 \mathrm{~km})$ are documented by Lannemezan$1 \& 2$ wells along the NPFT. The polygenic breccia, which are 


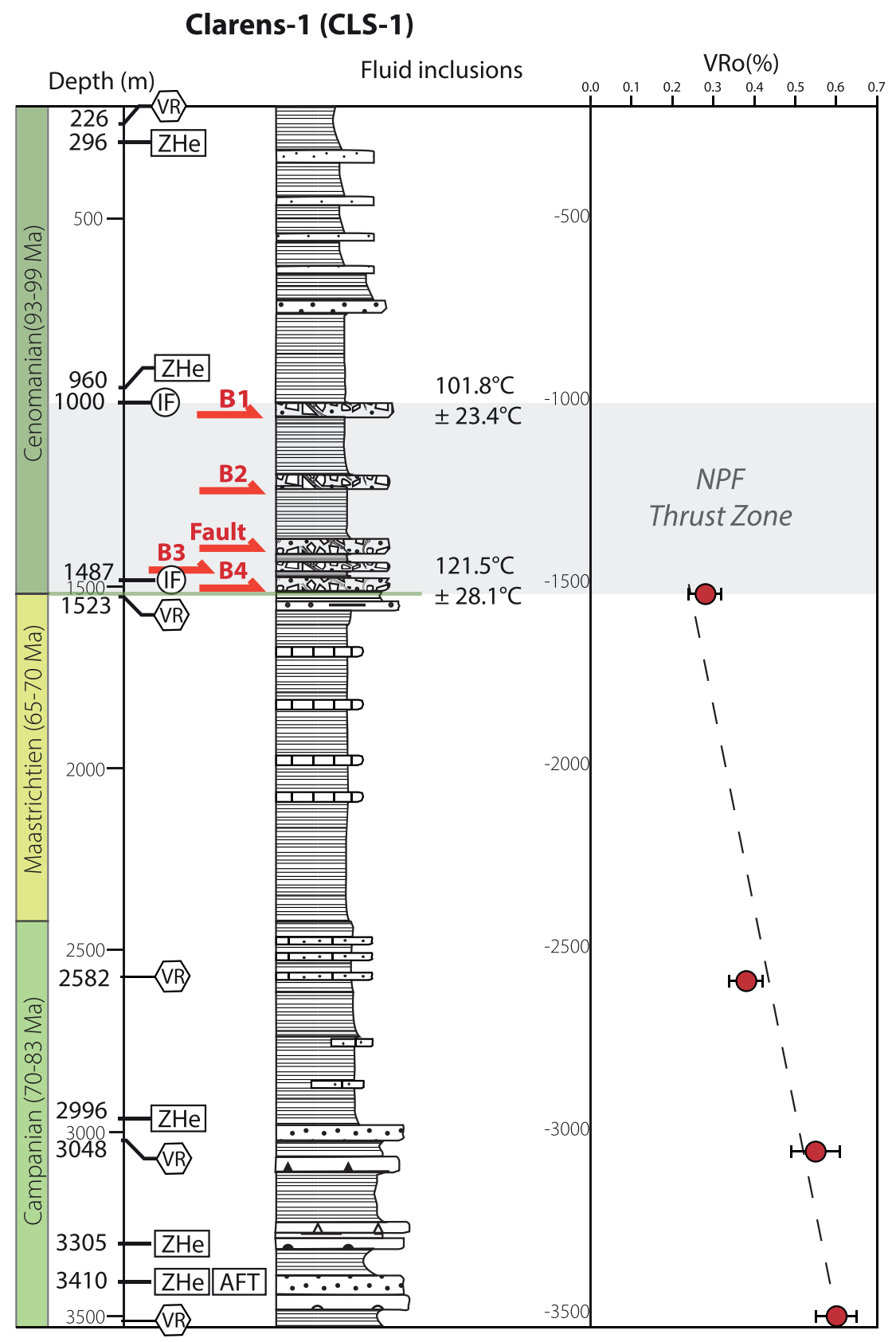

Fig. 2. Schematic log of the Clarens-1 (CLS-1) borehole with the vitrinite reflectance data used in this study. Note the $500 \mathrm{~m}$ large zone which presents the fault zone and the different levels of sedimentary breccia (B1 to B4) observed on the drill core. VR, AFT, ZHe and IF refer to the position of the Vitrinite Reflectance data, Apatite Fission Track sample, (U-Th)/He on zircons samples and fluid inclusions samples, respectively.

described below, were drilled in Lannemezan-2, Clarens-1, $2 \& 102$ wells and are located along the south-dipping NPFT.

North of the NPFT, in the Aquitaine Basin, the topbasement reflector is observed at $3 \mathrm{~s}$ TWT, indicating a thick $(\sim 7.5 \mathrm{~km})$ accumulation of sediments in the footwall. The NPFT is covered by Miocene and younger sediments. Below, the Eocene deposits show growth-stratal patterns defined by beds thickening towards the NPFT and wedging out to the frontal fold drilled at Recurt-1 (Fig. 3). By contrast, the Paleocene beds are isopachous. The thick Late Cretaceous (Santonian to Maastrichtian) accumulations that are inferred to mark the early stage of convergence show growth strata wedging toward the NPFT. These syn-convergence series further depict a large tight recumbent fold along the NPFT as documented by reverse dip measured in Lannemezan-1 \& 2 wells (Fig. 3). Although poorly dated in detail, the growth strata geometries suggest two phases of deformation associated with motion along the NPFT during the Santonian-Maastrichtian and in the Eocene times.

The bottom of the early syn-convergence sequences displays several apparent downlaps and show they were deposited unconformably above the post-rift sequence (Fig. 3). 

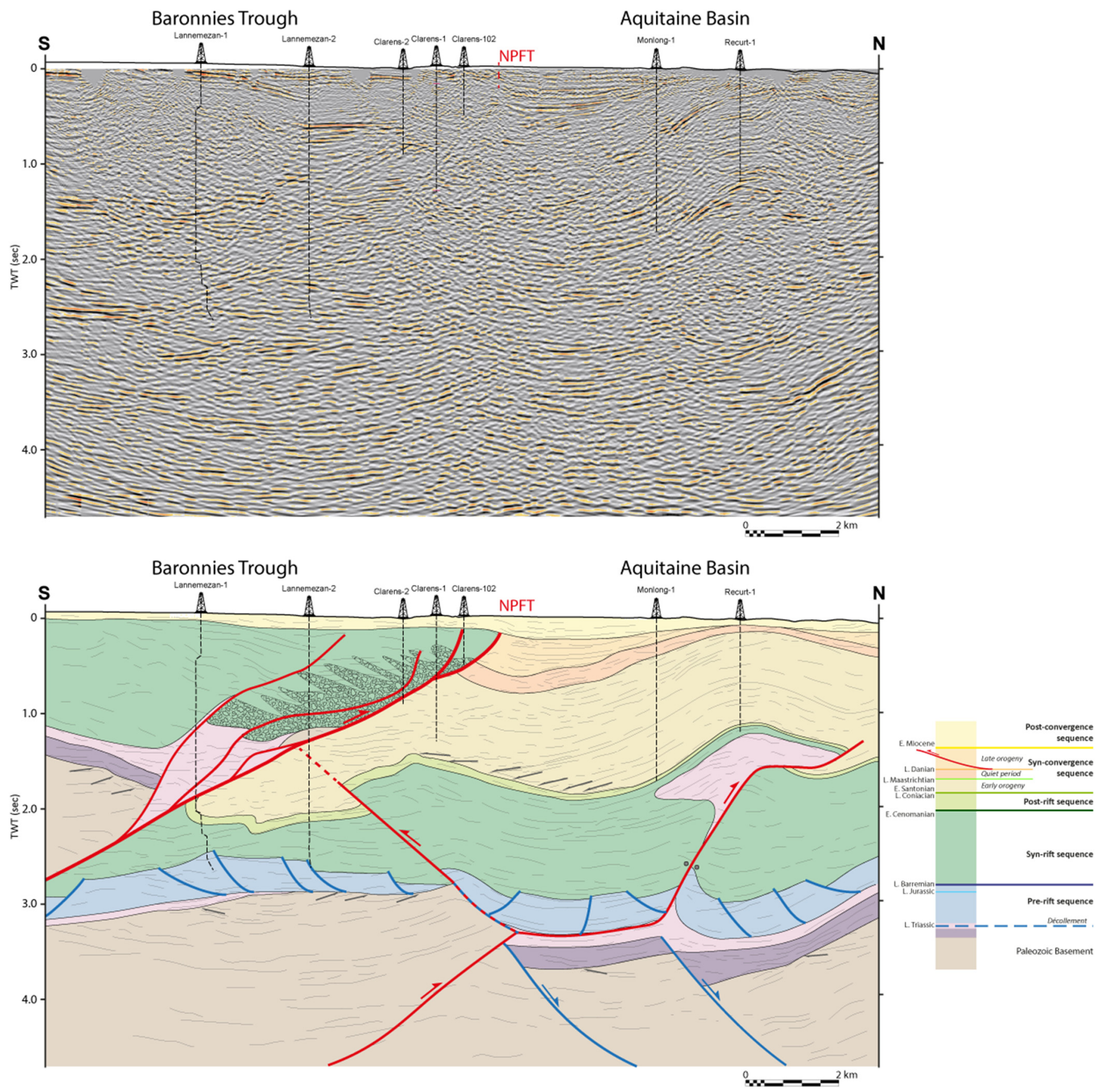

Fig. 3. Structure of the North Pyrenean Frontal Thrust along N-S profile located in the central Pyrenees (see Fig. 1 for location). (a) N-S Seismic reflection profile (85SAV2, courtesy of Total SE) with the position of Lannemezan-1 \& 2, Clarens-1, 2 \& 102, Monlong-1 and Recurt-1. (b) Section of the interpreted seismic profile and calibrated with wells. This section shows the geometry of the North Pyrenean Frontal Thrust, and the structure of the relatively preserved Aquitaine Basin. 


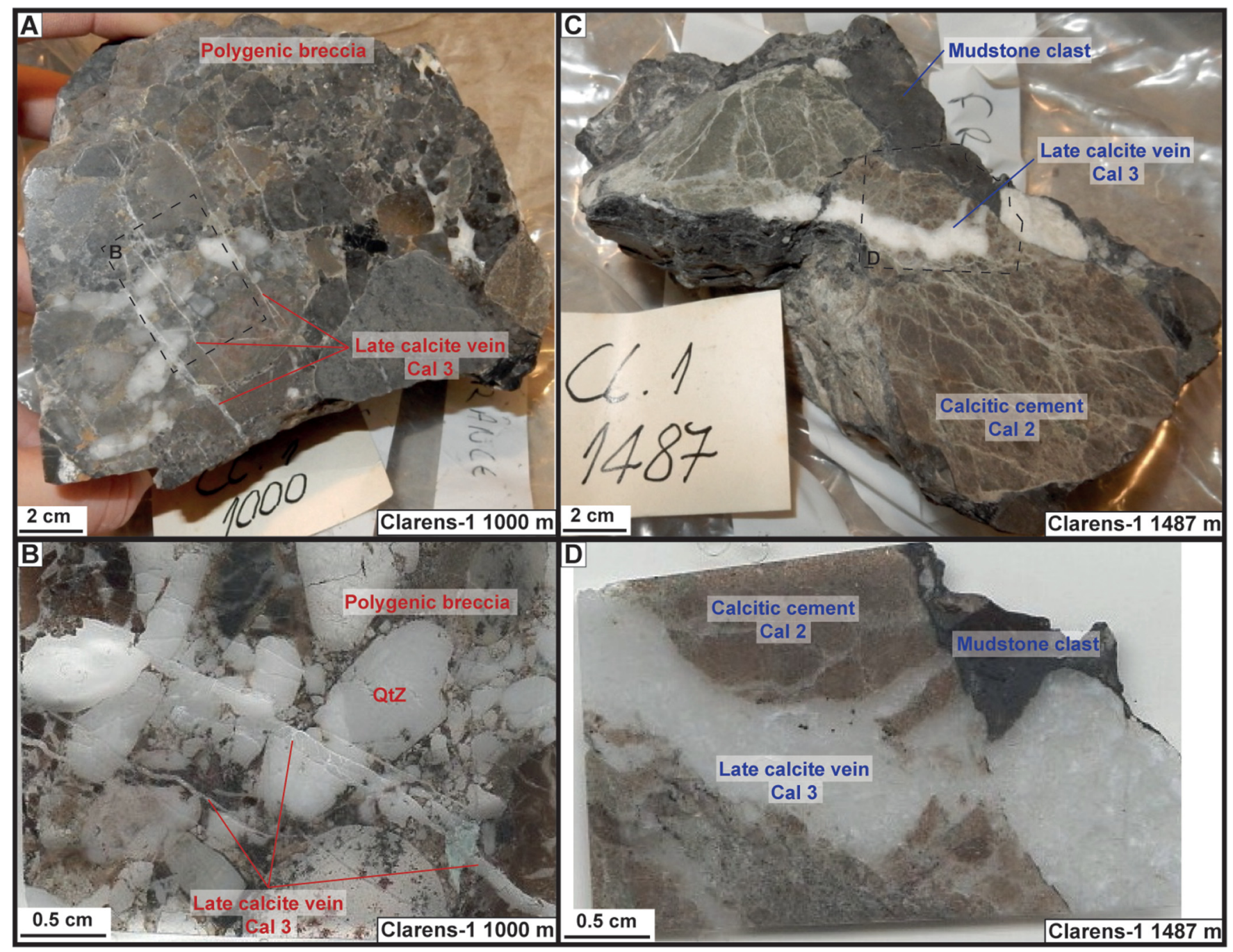

Fig. 4. Photographs of macroscopic samples and thin sections from Clarens-1 at $1000 \mathrm{~m}$ (A and B) and $1487 \mathrm{~m}(\mathrm{C}$ and $\mathrm{D})$ depth, showing the polygenic breccia of the NPF Thrust Zone crosscut by late calcite veins (Cal 3) used for fluid inclusions study.

They indicate that the underlying former rift template is sealed and relatively preserved from the collisional imprint.

The thickness of the post-rift sequence although calibrated in Monlong-1 et Rencurt-1 wells only appears to be isopachous in the footwall of the NPFT. The thickness of the underlying syn-rift sequence is determined in contrast by Lannemezan$1 \& 2$ in the south, as well as by Monlong- 1 and Recurt-1 in the north. These deposits show a constant thickness within the Aquitaine Basin. However, their thickness varies to the south as revealed by thinning toward the NPFT and where they are cross-cut by a welded salt diapir composed of the Upper Triassic evaporites (Fig. 3). The pre-rift sequence is discontinuous, anisopachous and is affected by normal faulting. In the northern part of the section, the pre-rift series overlying the Upper Triassic evaporites shows two synclines on both sides of a salt diapir. Underneath the Baronnies Trough and the NPFT, the pre-rift sequence becomes shallower and sits on the basement.

The top-basement geometry can be identified because of the high-amplitude reflectors and the top-lap, corresponding to the angular unconformity between the Lower Triassic deposits and the Variscan basement. Furthermore, As the pre-rift sediments (including Upper Triassic evaporites and Jurassic carbonates) accommodate the geometry of the basement (e.g. shift) their shape highlights the top-basement geometry. Basement-involved tilted blocks bounded by north-dipping normal faults are observed in the northern part of the section. Below the Clarens-1, the top-basement geometry shows a shift of $\sim 1 \mathrm{~s}$ TWT (also outlined by Permian-Triassic deposits), which correlates with the stretching recorded in the pre-rift cover and thick accumulations of syn-rift sediment.

This shift of the top-basement indicates the north-dipping normal fault was affected by subsequent deformation related to the collision event. This type of architecture can be observed further west in the neighboring Arzacq Basin (Ducoux et al., 2021a). The upper part of the tilted block is short-cut by a reverse thick-skinned fault forming a fish-tail structure in the Aquitaine Basin (Fig. 3). Part of the thick-skinned deformation was accommodated in the sedimentary cover by a back-thrust responsible for the shift of pre-, syn-, post-rift and synorogenic sediments toward the NPFT. The downlaps of the syn-orogenic sediments encapsulated the open fold related to 
this back-thrust. Below Recurt-1 and Monlong-1 wells, the displacement along the thick-skinned basement thrust ramp is seen to be accommodated in the weak Upper Triassic salt layer. The fault ramp then connects to the welded diapiric structure that affects the syn-rift sediments. This deformation is eventually accommodated in gentle folding of the synorogenic sediments (Fig. 3).

\subsection{Breccia and calcite vein petrography}

The core samples collected in Clarens-1 well across the NPFT fault zone are made of an alternation of breccias and marls. Breccias are encountered in the Cenomanian formation at $1000 \mathrm{~m}, 1241 \mathrm{~m}, 1388 \mathrm{~m}, 1442 \mathrm{~m}$ and $1487 \mathrm{~m}$ (Fig. 2). They are polygenic, containing clasts of sandstones, sub-angular quartz, dolomites, and fine-grained black siliciclastic argillites, cemented by calcite (Fig. 4). The different clast lithologies and the absence of cataclastic deformation argue for the sedimentary origin of the breccias. Such clasts probably come from the various sedimentary formations present at depth or have been emplaced during episodes of salt tectonics. Cataclastic deformation is encountered in marls and breccias between $1388 \mathrm{~m}$ and $1399 \mathrm{~m}$. They are made of sheared and striated marls surrounding clasts corresponding to the sedimentary breccias described above.

Four generations of calcite (as cements and veins) are observed at $1000 \mathrm{~m}$ (Fig. 5). The first one (Cal 0; Figs. 5B-5D) corresponds to a fracture formed in the sedimentary rock before its brecciation. The breccia is cemented by two nonluminescent calcites ( $\mathrm{Cal} 1$ and $\mathrm{Cal} 2$, the first being the least luminescent; Figs. 5B-5D) which are anterior to a luminescent calcite (Cal 3; Figs. 5B-5D). The breccias inside the NPFT fault zone is crosscut by calcite veins. It is noteworthy that the calcite veins are only observed in the breccias and not in the host Cenomanian marls. At $1489 \mathrm{~m}$, two generations of fractures are filled by similar luminescent calcite than Cal 3 observed at $1000 \mathrm{~m}$ (Fig. 5F).

\subsection{Fluid inclusions analysis}

Fluid inclusions (FIs) found in our two samples of Cal 3 are biphasic with the aqueous phase volumetrically dominant over the vapor phase (Fig. 6). They all homogenized into liquid phase. No oil-rich fluid inclusions were observed. In the two veins, FIs display similar salinity around $20.9 \pm 3.4 \mathrm{wt} \%$ eq. $\mathrm{NaCl}$. At $1000 \mathrm{~m}, T_{\mathrm{h}}$ values ranged between $63.1^{\circ} \mathrm{C}$ and $145.1^{\circ} \mathrm{C}$ with a mean at $101.8 \pm 23.4^{\circ} \mathrm{C}$; at $1487 \mathrm{~m}$ they show slightly higher $T_{\mathrm{h}}$ with a range between $72.2^{\circ} \mathrm{C}$ and $174.7^{\circ} \mathrm{C}$ and a mean at $121.5 \pm 28.1^{\circ} \mathrm{C}$ (Fig. 7; Tab. 1). Note that the observed minimum $T_{\mathrm{h}}\left(63.1^{\circ} \mathrm{C}\right)$ is higher than the present-day temperature in the borehole (around $36^{\circ} \mathrm{C}$ at $1500 \mathrm{~m}$; see Sect. 3), implying no $T_{\mathrm{h}}$ reset here. All the fluid inclusions analyzed are observed in intragranular planes in the calcite (Fig. 6), which indicates primary fluid inclusions (Van den Kerkhof and Hein, 2001). A large range of $T_{\mathrm{h}}$ values are measured for the same fluid inclusions plan, indicating that no petrographic feature can explain such a large range. For instance, inclusions 11 and 12 at $1000 \mathrm{~m}$ depth are located in the same plan (Fig. 6C) but show $T_{\mathrm{h}}$ at $109.0^{\circ} \mathrm{C}$ and $66.9^{\circ} \mathrm{C}$ respectively. Another example corresponds to inclusions 5 and 6 obtained at $1487 \mathrm{~m}$ depth (Fig. 6D) where $T_{\mathrm{h}}$ at $174.7^{\circ} \mathrm{C}$ and $72.2^{\circ} \mathrm{C}$ are measured. Eutectic temperatures $\left(T_{\mathrm{e}}\right)$ depend of the nature of the salt dissolved in the fluid inclusion. $T_{\mathrm{e}}$ between $-37.9{ }^{\circ} \mathrm{C}$ and $-45.8^{\circ} \mathrm{C}$ with a mean at $-41.7 \pm 2.9^{\circ} \mathrm{C}$ were determined at the $1000 \mathrm{~m}$ level (Tab. 1). Such $T_{\mathrm{e}}$ corresponds to a mixing between $\mathrm{NaCl}-\mathrm{CaCl}_{2}-\mathrm{H}_{2} \mathrm{O}$ and $\mathrm{NaCl}-\mathrm{MgCl}_{2}-\mathrm{H}_{2} \mathrm{O}$ systems which have $T_{\mathrm{e}}$ at $-37^{\circ} \mathrm{C}$ and $-52{ }^{\circ} \mathrm{C}$, respectively (Davis et al., 1990). A single $T_{\mathrm{e}}$ at $-64.5^{\circ} \mathrm{C}$ could be determined for the $1487 \mathrm{~m}$ level (Tab. 1) indicating a possible addition of $\mathrm{LiCl}$ or exhibit metastability (Cathelineau et al., 1994; Dubois et al., 2010).

\subsection{Vitrinite reflectance}

Vitrinite reflectance analysis reveals $\% \mathrm{R}_{\mathrm{o}}$ values increasing with depth from $0.28 \pm 0.04 \%$ in the upper part of the core samples $(1523 \mathrm{~m})$ to $0.60 \pm 0.05 \%$ in the lower part $(3501 \mathrm{~m}$; Tab. 2). These two estimates indicate that these samples are made of sediments with a low thermal maturity. Such low reflectance values in samples located in the footwall of the NPFT suggest a normal burial-dependant trend and equilibration under a gradient of $30^{\circ} \mathrm{C} / \mathrm{km}$.

\section{Discussion}

\subsection{Tectonic evolution}

\subsubsection{From syn-rift to post-rift evolution}

The increase of syn-rift sediment thickness in the hanging wall of the NPFT (Baronnies Trough) indicates the NPFT formed by the reactivation of a former south-dipping normal fault, bounding a hyperextended domain with mantle exhumation (Fig. 8A). Raman Spectroscopy on Carbonaceous Materials performed on sedimentary rocks of the Baronnies Trough further reveals that this basin experienced temperatures up to $480^{\circ} \mathrm{C}$ (Espurt et al., 2019; Ducoux et al., 2021b) indicating high thermal gradient achieved during hyperextension. The polygenic breccias observed in the Clarens-1 boreholes (Figs. 4A and 4B) are inferred to be proximal clastic sediments deposited in the hanging wall of a south-dipping normal fault (Fig. 8A). The thick accumulations of Upper Triassic evaporites documented by the Lannemezan-1 well, suggest that a large diapiric structure may have formed associated with this large-scale normal fault (Fig. 8A). The paleo-high located between the Baronnies Trough and the Aquitaine Basin is highlighted by the preservation of the prerift sequence and thinner syn-rift deposit sealed by a thin postrift deposit.

To the North, the vitrinite reflectance values shows normal depth-dependant burial in the footwall of the NPFT suggesting the rift-related thermal imprint was relatively modest (Fig. 2; Tab. 2). The northern margin of the basement high is bounded by a succession of high-angle normal faults shaping a succession of tilted blocks. The pre-rift sequence was detached along the Upper Triassic evaporites and folded during the ascent of a huge diapiric structure recognized in the Recurt-1 well. The spatial distribution of salt diapirs appears related to the location of the main basement-involved faults. During rifting, the extension and thinning was more important to the 

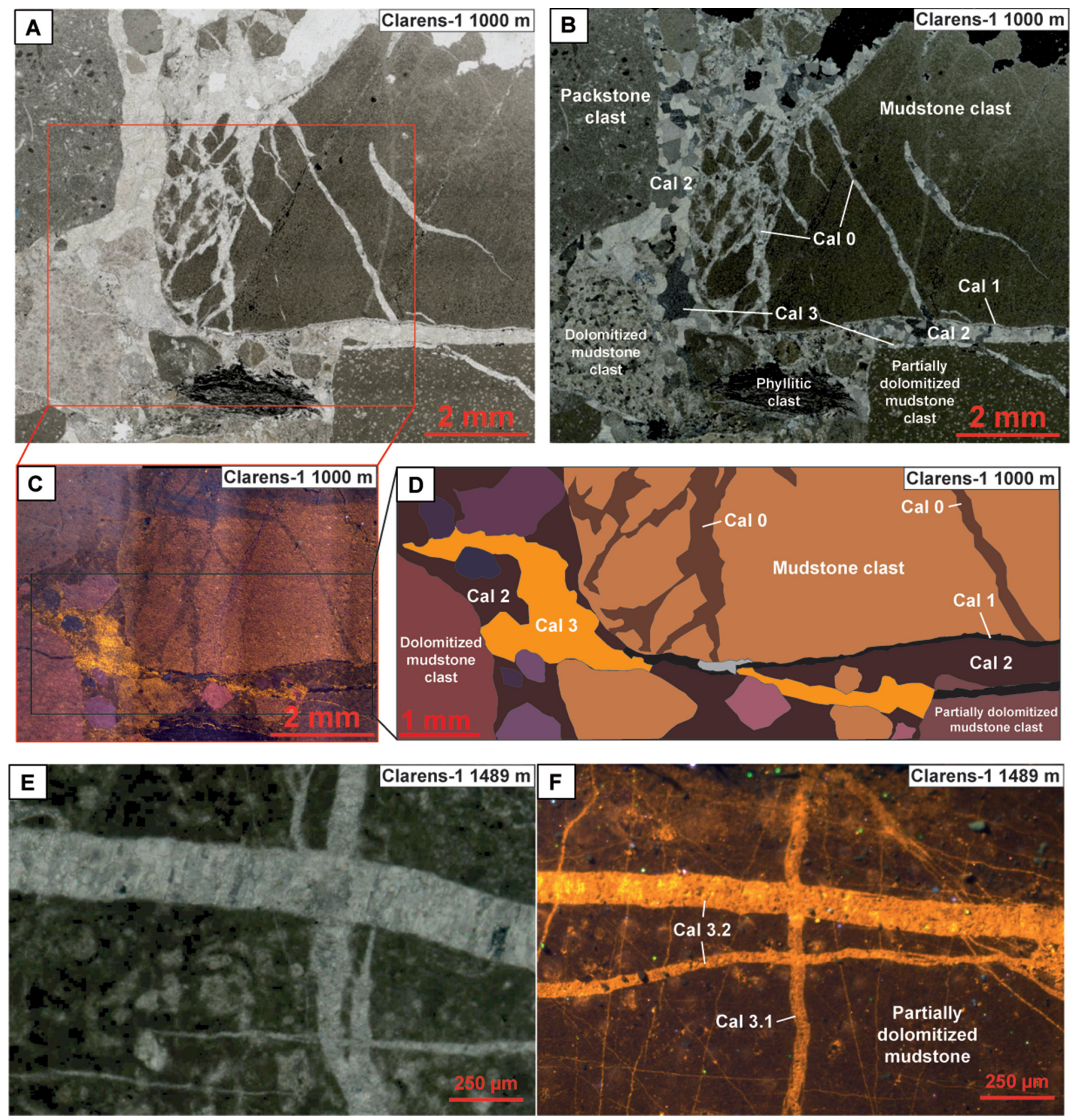

Fig. 5. (A) Plane polarized light image of the breccia observed at $1000 \mathrm{~m}$, and (B) the associated cross-polarized light image with the interpretation of the different clasts and veins. (C) Cathodoluminescence image of the same breccia observed in (A) and (B) with its interpretative sketch in (D). (E) Cross-polarized light image of the late calcite veins observed at $1487 \mathrm{~m}$. (F) Cathodoluminescence image of another zone of the same thin section as in (E). 
G. Barré et al:: BSGF 2021, 192, 52

Table 1. Fluid inclusions microthermometric data from Clarens-1 borehole at $1000 \mathrm{~m}$ and $1487 \mathrm{~m}$ depth.

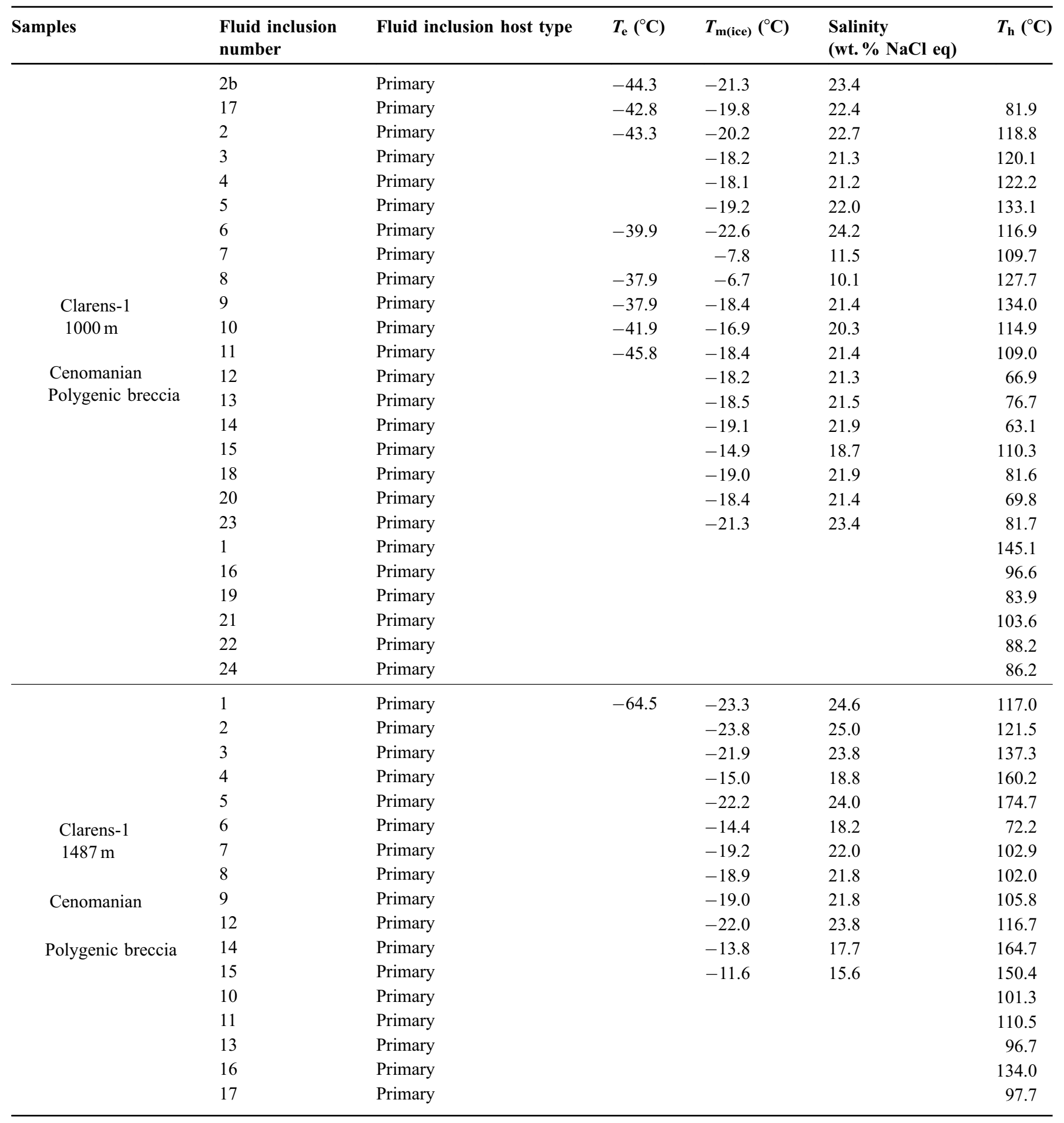




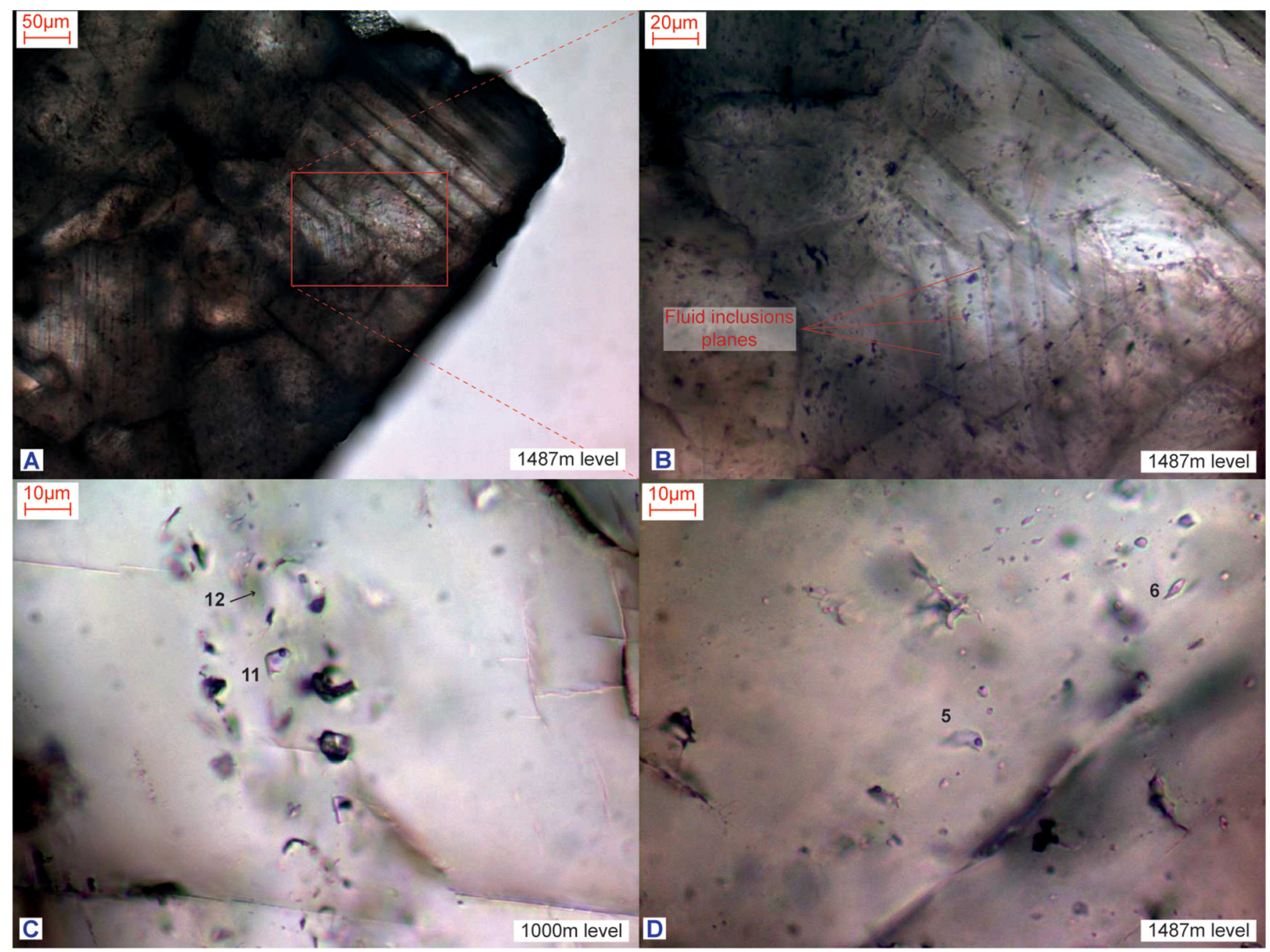

Fig. 6. (A and B) Microphotographs of typical fluid inclusions planes observed in the calcite cleavage. (C and D) Microphotographs of typical fluid inclusions observed in the two levels $(1000 \mathrm{~m}$ and $1487 \mathrm{~m})$ of the Clarens-1 well.

south (i.e., Baronnies Trough). This is suggested by the fact that pre-rift (Jurassic) supra-salt series are not recognized on the hanging wall of the southern normal fault. Due to decoupling in the Upper Triassic salt and the slope formed by the former normal fault, these series glided to the south and were disconnected from the pre-rift remnants located above the basement high.

\subsubsection{Timing of NPFT activity}

The transition from post-rift basin evolution to the onset of tectonic inversion along the NPFT can be inferred from the stratigraphic architecture observed in the footwall. Following the passive infilling of post-rift structures by early synconvergence deposits (Fig. 8A), the wedge geometry defined by overturned Santonian to Maastrichtian beds passing upward into flat-lying strata ahead of the thrust indicate the NPFT was active at this time, which is in agreement with inference from thermochronology (see Fillon et al., 2021 and description below). A part of deformation may have been accommodated by the weld of the diapiric structure localized along the former normal fault. Minor deformation is accommodated further north in a back-thrust structure which shows a small shift of the syn-convergence successions. The NPFT as well as this backthrust both result from the inversion of former normal faults. In the Aquitaine Basin, the deformation is also accommodated by the tightening of pre-existing salt diapirs as highlighted by fold geometry of the overlying syn-convergence deposits.

Fillon et al. (2021) used apatite fission track and (U-Th)/He on zircon along the Clarens- 1 borehole to evaluate the postorogenic vertical motions of the Aquitaine Basin in response to renewed erosion of the Axial Zone. The thermal modeling of the deeper samples has shown a clear signal of early-orogenic warming followed by slow Cenozoic cooling. While the uppermost samples show monotonic time-Temperature paths since Cenomanian times - close to surface or sub-surface temperatures (Fig. 8B, sample CLS-296) - the lowermost ones recorded heating at the same time. The best-fit scenario resolves a rapid heating event during the Campanian bringing the samples to a temperature of $120 \pm 20^{\circ} \mathrm{C}$ at $72 \pm 2 \mathrm{Ma}$ (Fig. 8B). 

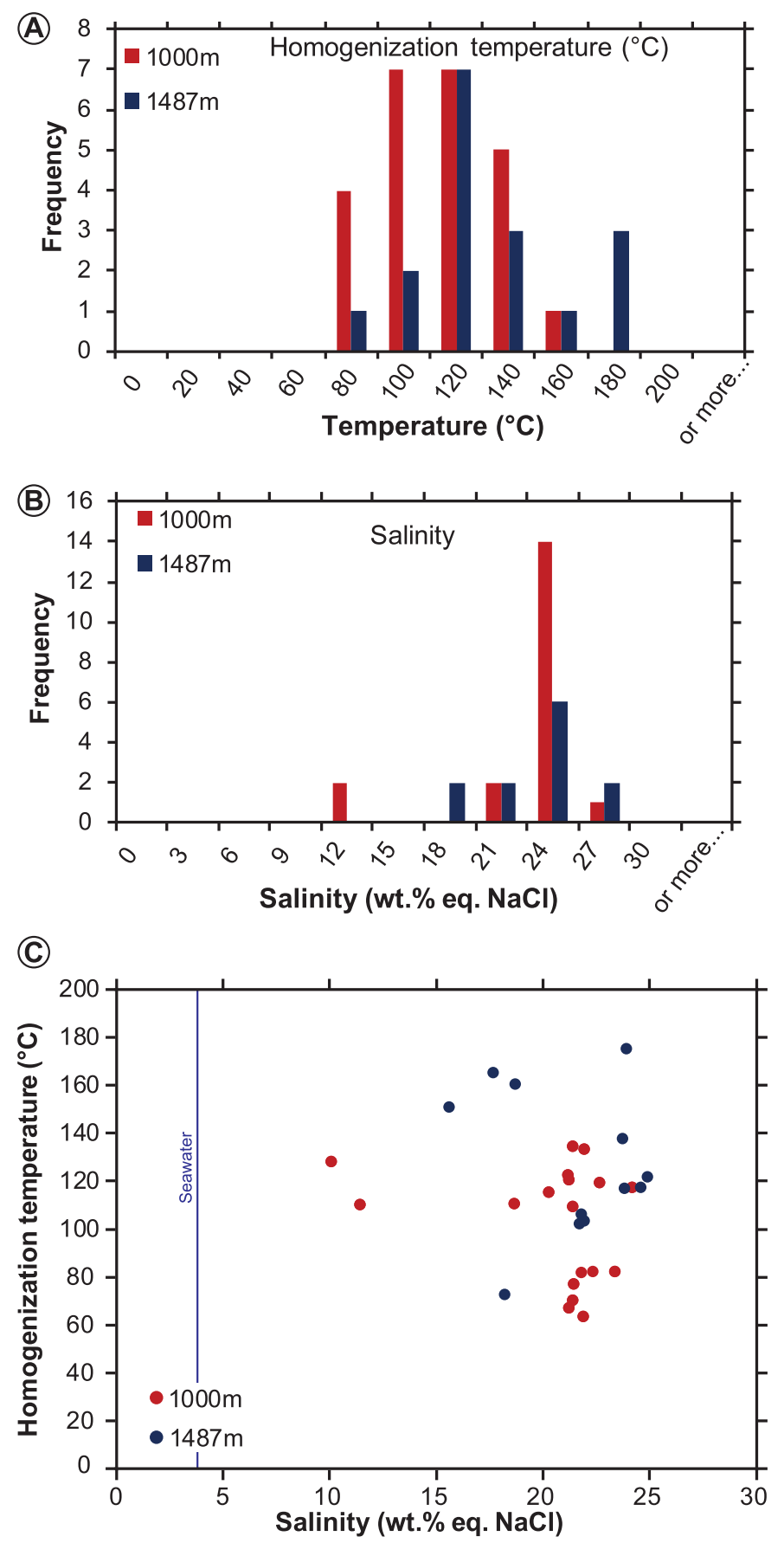

Fig. 7. Microthermometry results of fluid inclusions from Clarens-1 borehole (France). (A) Histogram of homogenization temperatures $\left(T_{\mathrm{h}}\right)$. (B) Histogram of salinity (wt.\% eq $\mathrm{NaCl}$ ). (C) Diagram $T_{\mathrm{h}} v s$. salinity.

Considering that the uppermost samples do not show any evidence for significant heating after deposition, we interpret the thermal event recorded by the lowermost samples as resulting from the burial induced by overthrusting of the North Pyrenean Frontal Thrust, which is in agreement with vitrinite results. This interpretation is also consistent with seismic reflection data that indicate a first phase of thrusting during the Campanian marked by the wedge-shaped thickening of the Campanian strata (Figs. 3 and 8).
After the early stage of convergence, during the Late Cretaceous, the observation that the Danian (Paleocene) deposits are locally isopachous reveal that the NPFT was inactive at this time (i.e., tectonic quiescence), but salt diapirism was likely ongoing as indicated by sediment thinning above the Recurt-1 diapir. Subsequently, the major syntectonic thickening of Eocene sediments figures the reactivation of the NPFT structure, in agreement with the syn-orogenic deformation and exhumation during Eocene-Oligocene times 
(Beaumont et al., 2000, Fitzgerald et al., 1999). This second tectonic phase during the Eocene-Oligocene times although supported by a second sediment wedge is not recorded by thermal modelling (Fillon et al., 2021), mainly because the burial may have been lower than $2-3 \mathrm{~km}$, requiring higher sensitivity thermochronometers such as (U-Th)/He on apatite to be resolved. Unfortunately, the low apatite yield of our samples did not allow us to perform such analysis.

\subsection{Fluid circulation: nature and timing}

\subsubsection{Timing of formation of breccias and calcite veins}

During the post-rift stage, the paleo-high formed between the Baronnies Trough and the Aquitaine Basin induced a break in slope along the former south-dipping normal fault, which triggered the formation of the sedimentary polygenic breccia observed in the Cenomanian formation with a probable contribution of the diapir (Fig. 8). A first fracturation event corresponding to calcite veins filled by $\mathrm{Cal} 0$ occurred before the formation of the breccias (Fig. 5D). Then, the joints of the breccia were filled by two generations of non-luminescent calcite: Cal 1 and Cal2. Precipitation of these two generations may have occurred before or during the Campanian activation of the NPFT. Cenomanian to Santonian period is known to be a post-rift period, without any documented major active tectonic structures. In the light of the structural and thermochronology results presented above, a Campanian activation has a much higher probability.

The last generation of calcite (Cal3), where the fluid inclusions were studied, crosscut the breccias revealing their late injection regarding the first activation of the NPFT. It is worth noting that the Cenomanian marls levels between the breccias are preserved from calcite cements, showing that the breccias were the preferential pathways for fluids circulation. The two generations of fractures observed at $1489 \mathrm{~m}$, suggest two pulses of fluid circulations. But the very similar luminescence and fluid inclusions composition (see in the following sub-section) between the veins at $1489 \mathrm{~m}$ and $\mathrm{Cal} 3$ observed at $1000 \mathrm{~m}$, suggest a similar fluid for $\mathrm{Cal} 3$ at these two depths. In addition, the similar salinity of fluid inclusions analyzed at $1000 \mathrm{~m}$ and $1487 \mathrm{~m}$ strongly suggests a similar origin for these late fluids. Thus, we interpret that the late calcite veins (i.e., Cal3), cross-cutting the breccias, were generated from the same fluids which originated from the leaching of Triassic evaporites at depth (please see below).

The transition from a stage of joints filling by Cal 1 and $\mathrm{Cal} 2$ to a fracturing of the whole breccia by the Cal 3 veins, necessarily implies a lag time without major tectonic influence. We suggest that the tectonic quiescence of about $>10 \mathrm{Ma}$ between the two activations of the NPFT, corresponds to this transition. This period possibly allowed consolidation of the breccia making it impermeable (such a breccia consolidation was already observed in the South-Pyrenean Zone; Travé et al., 2007). It implies that the calcite veins are late regarding the first NPFT activation and the quiescence time. Thus, they are probably associated with the Eocene-Oligocene reactivation of the thrust, marked by the growth strata observed in Figure 3.

An absolute dating of the calcite veins was attempted using the $\mathrm{U} / \mathrm{Pb}$ method to validate their age. Unfortunately, the concentrations of uranium and lead were too low (about tens of $\mathrm{ppb})$ in the calcite to determine an absolute age.

\subsubsection{Evaporitic origin of the fluid}

Fluid inclusions observed in the calcite veins (Cal3) from both $1000 \mathrm{~m}$ and $1487 \mathrm{~m}$ levels of the Clarens- 1 borehole show very high salinities (up to $25 \mathrm{wt} . \%$ eq. $\mathrm{NaCl}$ ). Thanks to eutectic temperatures, the fluid composition can be determined as a $\mathrm{NaCl}-\mathrm{CaCl}_{2}-\mathrm{MgCl}_{2}-\mathrm{H}_{2} \mathrm{O}( \pm \mathrm{LiCl})$ system. Such high salinity and complex composition are in agreement with brines generated by evaporite leaching (e.g., Goldstein, 2001; Yardley and Graham, 2002). No discrimination can be made between the fluid circulating at $1000 \mathrm{~m}$ and $1487 \mathrm{~m}$, suggesting a fluid with same origin in the veins observed in the NPFT zone. The only difference between fluid inclusions from the hanging wall and the footwall (Fig. 2) is the temperature. The large variation of $T_{\mathrm{h}}$ with similar salinity and salt composition (i.e., same $T_{\mathrm{e}}$ ) cannot be explained through petrographic observations. The different $T_{\mathrm{h}}$ values observed in a same fluid inclusion plane as well as the absence of post-entrapment modification suggest the cooling of a relatively continuous fluid flow from one source which is recorded in a single generation of fluid inclusions. Such an effect has already been observed in the décollement layer within Upper Triassic evaporites of the Alps (Barré et al., 2020), as reflecting the cooling of a single fluid circulation during the retrograde metamorphism of the Alpine collision. The occurrence of Triassic evaporites within the NPFT fault zone is inferred from borehole data and our structural interpretation (Figs. 3 and 8). This pleads for a unique evaporitic origin for the fluids that percolated along the NPFT and that are recorded in the late Cal 3 veins.

The temperature difference inferred from fluid inclusions between the upper $\left(101.8^{\circ} \mathrm{C} \pm 23.4^{\circ} \mathrm{C}\right.$ at $1000 \mathrm{~m}$ depth $)$ and lower $\left(121.5^{\circ} \mathrm{C} \pm 28.1^{\circ} \mathrm{C}\right.$ at $\left.1487 \mathrm{~m}\right)$ levels of the thrust zone, probably reflects temperature difference in the source of the fluids (i.e., Triassic evaporites present in depth). Assuming a thermal gradient around $40^{\circ} \mathrm{C} / \mathrm{km}$, we estimate that the fluid was generated between 2.5 and $3.0 \mathrm{~km}$ deep. Lannemezan$1 \& 2$ wells penetrate the Triassic evaporites between 2153 and $2636 \mathrm{~m}$ and between 2386 and $4727 \mathrm{~m}$ depth, respectively. A Triassic origin for the last fluid circulation generated by the leaching of evaporites is therefore strongly suggested here.

\subsubsection{Agreement with the late fluid circulation in the Pyrenees}

Most of the fluid circulations studied in the Pyrenees emphasize the contribution of evaporites in the composition of fluids (McCaig et al., 2000; Travé et al., 2000; Salardon et al., 2017; Corre et al., 2018; Crognier et al., 2018; Quesnel et al., 2019; Incerpi et al., 2020). A recent review from Cathelineau et al. (2021) showed that evaporitic-related fluids are ubiquitous throughout the geological history of the Pyrenees. These fluids are mixed in different proportions with more dilute water sources (e.g., meteoric water, seawater...) inducing the recording of a relatively wide salinity range in the fluid inclusions. Therefore, by using salinity, it is not possible to determine whether the fluid circulated during the rifting or during the compression phase of the orogen.

To resolve this critical parameter, most of the studies in the Pyrenees have used structural evidence to characterize the timing of fluid circulations they observed (Travé et al., 1998, 


\section{A- Geological scenario}

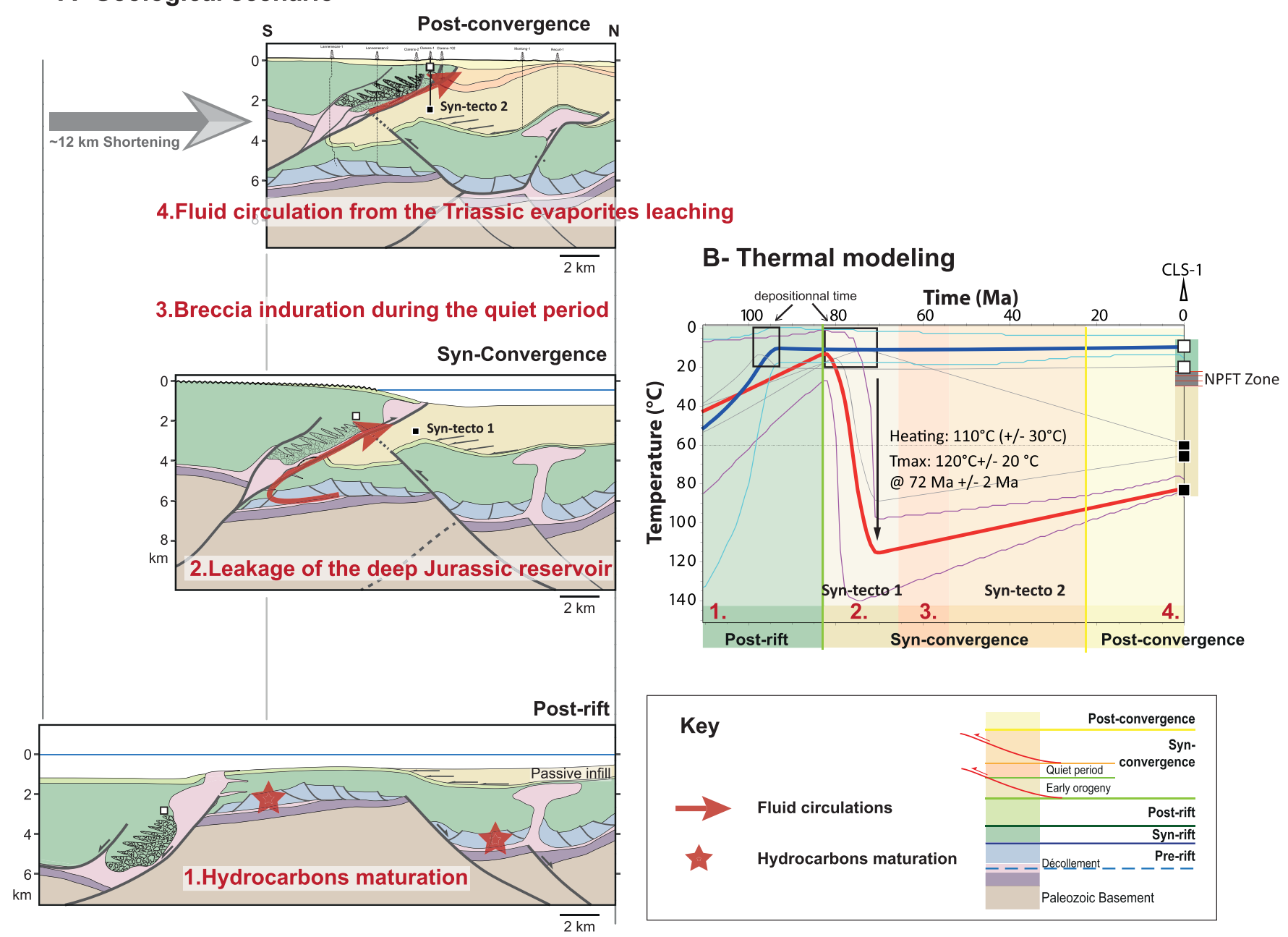

Fig. 8. (A) Restored cross-sections of Figure 3 with associated fluid flows in space and time. (B) Time-temperature paths from the thermal inverse modeling from Fillon et al. (2021).

Table 2. Mean vitrinite reflectance (VRo) data from $224 \mathrm{~m}$ to $3501 \mathrm{~m}$ depth from the Clarens-1 borehole.

\begin{tabular}{|c|c|c|c|c|}
\hline \multicolumn{5}{|c|}{ Clarens-1 } \\
\hline 224.0 & Cenomanian & - & - & - \\
\hline 1523.0 & Maastrichtian & 0.28 & 0.04 & 45 \\
\hline 2582.4 & Campanian & 0.38 & 0.04 & 60 \\
\hline 3048.4 & Campanian & 0.55 & 0.06 & 50 \\
\hline
\end{tabular}

S.D.: standard deviation; $\mathrm{n}$ : number of measurements.

Table 3. Isotopic and chemical composition of the gas from Lannemezan-2 borehole (data from Lacrampe, 1990).

\begin{tabular}{lllllllllll}
\hline Well & Age & $\begin{array}{l}\delta^{13} \mathrm{C} \mathrm{CO}_{2} \\
(\% \circ \mathrm{C}-\mathrm{PDB})\end{array}$ & $\begin{array}{l}\delta^{13} \mathrm{C} \mathrm{CH}_{4} \\
(\% \mathrm{O}-\mathrm{PDB})\end{array}$ & $\mathrm{N}_{2}(\%)$ & $\mathrm{CO}_{2}(\%)$ & $\mathrm{H}_{2} \mathrm{~S}(\%)$ & $\mathrm{CH}_{4}(\%)$ & $\mathrm{C}_{2} \mathrm{H}_{6}(\%)$ & $\mathrm{C}_{3} \mathrm{H}_{8}(\%)$ & $\mathrm{iC4}(\%)$ \\
\hline Lannemezan-2 $6137 \mathrm{~m}$ & Tithonian & -2.6 & -37.1 & 0.71 & 4.00 & 0.69 & 94.24 & 0.31 & 0.03 & 0.02 \\
\hline
\end{tabular}


2000; Lacroix et al., 2014; Beaudoin et al., 2015; Crognier et al., 2018). Using this technique, most of the fluid circulations observed are associated with the compressive stage of orogeny. A single study shows fluid circulations related to the extensive stage using structural evidence (Salardon et al., 2017). A few studies have used absolute dating to determine the exact timing of fluid circulation (Incerpi et al., 2020; Motte et al., 2021). So far, they have only obtained ages showing fluid circulation during the extension phase. Recent studies used thermochronological tools to estimate the age of circulated fluids in faults (Milesi et al., 2019, 2020). They showed that in the Têt fault in the Axial Zone, fluids circulated during the compression phase. However, no fluid inclusion or isotopic study was coupled with these studies making it impossible to determine the nature of these fluids.

Here, it is the first time in the Pyrenees that a study of fluid inclusions has been associated with seismic and thermochronological data. It allowed to determine that the last fluid (i.e., Paleogene fluids) circulated in the NPFT was highly saline and generated by the leaching of the Triassic evaporites during the Eocene-Oligocene reactivation of the fault. This is consistent with the late fluid circulations observed in the Chaînons Béarnais (NPZ) showing a high salinity around $18 \mathrm{wt}$ $\%$ eq. $\mathrm{NaCl}$ (Motte et al., 2021). In the Aquitaine Basin, compression fluids have very low salinities around or below seawater (Renard et al., 2019; Elias-Bahnan et al., 2020), while the late fluid circulations observed in the South Pyrenean Zone have low salinity around $7 \mathrm{wt} \%$ eq. $\mathrm{NaCl}$ (Travé et al., 1998; Crognier et al., 2018). In all cases, meteoric water is assumed to be the main source of fluids with varying influence of evaporite leaching. Here, the Triassic evaporites are present in relatively low depth and are directly incorporated into the NPFT. It can therefore be assumed that, as in the other parts of the Pyrenees, the meteoric waters infiltrated to the evaporites, leached them, then warmed up leading to the late fluid circulation analyzed here in the calcite veins (Cal3). The proximity of the evaporites and the presence of the NPFT as a preferential pathway for fluid circulation (see below), may explain why the fluids are saltier here than in the other late fluid circulations observed elsewhere in the Pyrenees. This is consistent with the conclusions of Cathelineau et al. (2021).

\subsection{The conduit and barrier role of the NPFT}

The association of breccias and veins observed in the NPFT is consistent with a model of conduit-barrier fault where fluid circulations are preferentially located in the fault zone (Caine et al., 1996; Bense and Person, 2006). The breccias formed earlier than the veins. This suggests that the NPFT acted as a barrier and then as a conduit, the latter being evidenced by the late calcite veins analyzed in this study. The late fluids recorded in these veins originate from the Triassic evaporites present deeper (see previous section). However, at depth the Lannemezan-2 borehole reached a deep Jurassic hydrocarbon reservoir at $6137 \mathrm{~m}$, and based on the crosssection (Fig. 3) informed by seismic and well data this reservoir is connected to the NPFT. One may assume that hydrocarbons should then be observed in the late veins. But no hydrocarbons (oil or gas) are observed in these veins. Moreover, no gas was found in Clarens- 1 and Clarens-2 boreholes in contrast to the Lannemezan-2 borehole where gas are present and composed by $94.24 \%$ of $\mathrm{CH}_{4}$ and minor $\mathrm{CO}_{2}$ (4.00\%), $\mathrm{N}_{2}(0.71 \%), \mathrm{H}_{2} \mathrm{~S}(0.69), \mathrm{C}_{2} \mathrm{H}_{6}(0.31 \%), \mathrm{C}_{3} \mathrm{H}_{8}$ $(0.03 \%)$ and $\mathrm{iC}_{4} \mathrm{H}_{10}(0.02 \%$; Tab. 3). We suggest that the upper part of the NPFT acted as a conduit while the lower part of the fault acted as a barrier. Such a variation can be due to the Triassic evaporites present between the two reservoirs (Fig. 3) which may act as an impermeable formation preventing the rise of deep fluids through the NPFT.

Moreover, the gas composition and the isotopic signature of Lannemezan reservoir differ from the global gas composition in the other reservoirs found in the Aquitaine Basin with higher methane content and more enriched carbon isotope signatures (Lacrampe, 1990). According to Milkov and Etiope (2018), the combined carbon isotope signatures of $\mathrm{CH}_{4}$ $\left(\delta^{13} \mathrm{C}=-37.1 \%\right.$ V-PDB $)$ and $\mathrm{CO}_{2}\left(\delta^{13} \mathrm{C}=-2.6 \%\right.$ V-PDB; Tab. 3) indicate that Lannemezan gas is a late mature thermogenic gas. The other reservoirs found in the Aquitaine Basin show $\mathrm{CH}_{4}$ and $\mathrm{CO}_{2}$ carbon isotopes values around $-43.4 \% \pm \pm 1.9$ and $-1.1 \%_{0} \pm 3.9$, respectively (Lacrampe, 1990), which are values representative of an oil-associated thermogenic gas (i.e., less mature hydrocarbons; Milkov and Etiope, 2018). The different gas composition in Lannemezan reservoir may result either from its proximity to the NPZ where high rift-related temperatures have been reported (e.g., Dauteuil and Ricou, 1989; Clerc and Lagabrielle, 2014; Clerc et al., 2015; Ducoux et al., 2021b); or reflects an early leakage from the reservoir before sealing either by breccia consolidation and/or by evaporites.

However, the vitrinite reflectance data from the sedimentary pile located below the NPFT footwall, that is, in the same structural position as the Lannemezan reservoir, show a normal geothermal gradient (see above). We therefore suggest that the NPFT first acted as a conduit during the extension and/or early convergence leading to the Lannemezan Jurassic reservoir leak. Then, the long period of time $>10 \mathrm{Ma}$ that lasted between the two tectonic activities of the NPFT probably promoted the consolidation of the breccia causing the NPFT to act as a fluid barrier. Finally, the tectonic inversion led to the incorporation of the Triassic evaporites in the NPFT. The impermeable evaporites present in the fault resulted in the compartmentalization of the fluids between the upper and lower parts of the fault. This explains why there is no gas in the Clarens boreholes while there is still mature gas in the Lannemezan reservoir.

Further studies are certainly needed to validate this hypothesis, but so far it remains the most likely explanation.

\section{Conclusions}

This is the first study in the Pyrenees that combined fluid inclusions study to thermochronological studies in a structural framework. It documents late Eocene-Oligocene fluid circulations and long-term thermicity during two phases of thrusting across the North Pyrenean Frontal Thrust. We draw the following conclusions:

- By coupling structural study and inverse modeling of thermochronological data we conclude that the NPFT 
activity was initiated by the inversion of a normal fault during the Campanian time and reactivated in the EoceneOligocene time.

- The Eocene-Oligocene fluid/rock interaction history reveals circulation of a fluid derived from Triassic evaporitic levels which filled late calcite veins (named Cal 3 here) that affect the Albo-Cenomanian sedimentary breccias. This is in agreement with the recent review on the influence of the evaporites on fluid circulation in the Pyrenees (Cathelineau et al., 2021).

- These data are completed by the isotopic signature and composition of the gas from the Lannemezan reservoir. These highlight the role of the NPFT as a conduit and barrier for fluids between its different activations, separated by a time lapse of more than $10 \mathrm{Ma}$.

We show that during their polyphase tectonic history, large-scale structures at the orogenic front like NPFT can act as fluid flow conduits and lead to the leakage of oil and gas fields. Later in their history they can act as a fluid barrier. Although more studies are needed to better characterize the timing of the leakage role of the NPFT, the multi-method study of these main structures can provide significant inputs for both oil and mining exploration.

Acknowledgment. This work was conducted in the framework of the Fluids and OROGEN projects, cofunded by TOTAL S.A., BRGM and CNRS. The authors would like to thank Sabine Delahaye for her help on borehole calibration, Vanessa Dyja-Person from ${ }^{\circledR}$ HES Expertise Services for fluid inclusions analysis, and Jessica Saiag from Total Laboratory CSTJF Pau, for the optical and cathodoluminescence analysis. The authors also thank Jocelyn Barbarand, Philippe Boulvais and two anonymous reviewers for thorough, thought-provoking reviews which substantially improved our initial submission. We thank BSGF-Earth Sciences Bulletin Editor, Olivier Lacombe, for his comments and editorial support.

\section{References}

Angrand P, Ford M, Watts AB. 2018. Lateral variations in foreland flexure of a rifted continental margin: The Aquitaine Basin (SW France). Tectonics 37(2): 430-449.

Azambre B, Rossy M. 1976. Le magmatisme alcalin d'âge crétacé, dans les Pyrénées occidentales et l'Arc basque; ses relations avec le métamorphisme et la tectonique. Bulletin de la société Géologique de France 7(6): 1725-1728.

Barré G, Strzerzynski P, Michels R, Guillot S, Cartigny P, Thomassot E, et al. 2020. Tectono-metamorphic evolution of an evaporitic décollement as recorded by mineral and fluid geochemistry: The "Nappe des Gypses" (Western Alps) case study. Lithos 358: 105419.

Beamud E, Muñoz JA, Fitzgerald PG, Baldwin SL, Garcés M, Cabrera L, et al. 2011. Magnetostratigraphy and detrital apatite fission track thermochronology in syntectonic conglomerates: constraints on the exhumation of the South-Central Pyrenees. Basin Research 23(3): 309-331.

Beaudoin N, Huyghe D, Bellahsen N, Lacombe O, Emmanuel L, Mouthereau F, et al. 2015. Fluid systems and fracture development during syn-depositional fold growth: An example from the Pico del
Aguila anticline, Sierras Exteriores, southern Pyrenees, Spain. Journal of Structural Geology 70: 23-38.

Beaumont C, Muñoz JA, Hamilton J, Fullsack P. 2000. Factors controlling the Alpine evolution of the central Pyrenees inferred from a comparison of observations and geodynamical models. Journal of Geophysical Research: Solid Earth 105(B4): 81218145 .

Bense VF, Person MA. 2006. Faults as conduit-barrier systems to fluid flow in siliciclastic sedimentary aquifers. Water Resources Research 42: W05421.

Bernus-Maury C. 1984. Étude des paragenèses caractéristiques du métamorphisme mésozoïque dans la partie orientale des Pyrénées (French). Paris 6.

Boles JR, Eichhubl P, Garven G, Chen J. 2004. Evolution of a hydrocarbon migration pathway along basin-bounding faults: Evidence from fault cement. AAPG bulletin 88(7): 947-970.

Caine JS, Evans JP, Forster CB. 1996. Fault zone architecture and permeability structure. Geology 24(11): 1025-1028.

Cathelineau M, Marignac C, Boiron MC, Gianelli G, Puxeddu M. 1994. Evidence for Li-rich brines and early magmatic fluid-rock interaction in the Larderello geothermal system. Geochimica et Cosmochimica Acta 58(3): 1083-1099.

Cathelineau M, Boiron MC, Jakomulski H. 2021. Triassic evaporites: A vast reservoir of brines mobilised successively during rifting and thrusting in the Pyrenees. Journal of the Geological Society. https:// doi.org/10.1144/jgs2020-259.

Charrière A, Durand-Delga M. 2004. Le jeu fini-Crétacé du front nord-pyrénéen aux environs de Cucugnan (Corbières méridionales, Aude, France). Comptes Rendus Geoscience 336(13): 1199-1208.

Clerc C, Lagabrielle Y. 2014. Thermal control on the modes of crustal thinning leading to mantle exhumation: Insights from the Cretaceous Pyrenean hot paleomargins. Tectonics 33: 1340-1359.

Clerc C, Lagabrielle Y, Neumaier M, Reynaud JY, de Saint Blanquat M. 2012. Exhumation of subcontinental mantle rocks: Evidence from ultramafic-bearing clastic deposits nearby the Lherz peridotite body, French Pyrenees. Bulletin de la Société géologique de France 183(5): 443-459.

Clerc C, Boulvais P, Lagabrielle Y, de Saint Blanquat M. 2013. Ophicalcites from the northern Pyrenean belt: a field, petrographic and stable isotope study. International Journal of Earth Sciences 103(1): 141-163.

Clerc C, Lahfid A, Monie P, Lagabrielle Y, Chopin C, Poujol M, et al. 2015. High-temperature metamorphism during extreme thinning of the continental crust: A reappraisal of the North Pyrenean passive paleomargin. Solid Earth 6: 643-668.

Connan J, Lacrampe-Couloume G. 1993. The origin of the Lacq superieur heavy oil accumulation and the giant Lacq inferieur gas field. Applied Petroleum Geochemistry 3: 464-488.

Corre B, Boulvais P, Boiron MC, Lagabrielle Y, Marasi L, Clerc C. 2018. Fluid circulations in response to mantle exhumation at the passive margin setting in the north Pyrenean zone, France. Mineralogy and Petrology 112(5): 647-670.

Crognier N, Hoareau G, Aubourg C, Dubois M, Lacroix B, Branellec M, et al. 2018. Syn-orogenic fluid flow in the Jaca Basin (south Pyrenean fold and thrust belt) from fracture and vein analyses. Basin Research 30(2): 187-216.

Cruset D, Cantarero I, Vergés J, John CM, Muñoz-López D, Travé A. 2018. Changes in fluid regime in syn-orogenic sediments during the growth of the south Pyrenean fold and thrust belt. Global and Planetary Change 171: 207-224.

Davis DW, Lowenstein TK, Spencer RJ. 1990. Melting behavior of fluid inclusions in laboratory-grown halite crystals in the systems 
$\mathrm{NaCl}-\mathrm{H}_{2} \mathrm{O}, \quad \mathrm{NaCl}-\mathrm{KCl}-\mathrm{H}_{2} \mathrm{O}, \quad \mathrm{NaCl}-\mathrm{MgCl}_{2}-\mathrm{H}_{2} \mathrm{O}$, and $\mathrm{NaCl}-$ $\mathrm{CaCl}_{2}-\mathrm{H}_{2} \mathrm{O}$. Geochimica et Cosmochimica Acta 54(3): 591-601.

Dauteuil O, Ricou LE. 1989. Une circulation de fluides de hautetemperature a l'origine du metamorphisme cretace nord-pyreneen. Circ. High-Temp. Fluids Orig. North Pyrenean Cretac. Metamorph. Geodinamica Acta 3: 237-250.

Dubois M, Monnin C, Castelain T, Coquinot Y, Gouy S, Gauthier A, et al. 2010. Investigation of the $\mathrm{H}_{2} \mathrm{O}-\mathrm{NaCl}-\mathrm{LiCl}$ System: A synthetic fluid inclusion study and thermodynamic modeling from $-50{ }^{\circ} \mathrm{C}$ to $+100{ }^{\circ} \mathrm{C}$ and up to $12 \mathrm{~mol} / \mathrm{kg}$. Economic Geology 105 (2): 329-338.

Ducoux M, Jolivet L, Callot J-P, Aubourg C, Masini E, Lahfid A, et al. 2019. The Nappe des Marbres Unit of the Basque-Cantabrian Basin: The tectono-thermal evolution of a fossil hyperextended rift basin. Tectonics 38(11): 3881-3915.

Ducoux M, Masini E, Tugend J, Gómez-Romeu J, Calassou S. 2021a. Basement-decoupled hyperextension rifting: The tectono-stratigraphic record of the salt-rich Pyrenean necking zone (Arzacq Basin, SW France). GSA Bulletin. https://doi.org/10.1130/ B35974.1.

Ducoux M, Jolivet L, Masini E, Augier R, Lahfid A, Bernet M, et al. 2021 b. Distribution and intensity of high-temperature low-pressure metamorphism across the Pyrenean-Cantabrian belt: Constraints on the thermal record of the pre-orogenic hyperextension rifting. Bulletin de la Société géologique de France 192: 43. https://doi. org/10.1051/bsgf/2021029.

Eichhubl P, Davatz NC, Becker SP. 2009. Structural and diagenetic control of fluid migration and cementation along the Moab fault, Utah. AAPG Bulletin 93(5): 653-681.

Elias-Bahnan A, Carpentier C, Pironon J, Ford M, Ducoux M, Barré $\mathrm{G}$, et al. 2020. Impact of geodynamics on fluid circulation and diagenesis of carbonate reservoirs in a foreland basin: Example of the Upper Lacq reservoir (Aquitaine Basin, SW France). Marine and Petroleum Geology 111: 676-694.

Espurt N, Angrand P, Teixell A, Labaume P, Ford M, de Saint Blanquat M, et al. 2019. Crustal-scale balanced cross-section and restorations of the Central Pyrenean belt (Nestes-Cinca transect): Highlighting the structural control of Variscan belt and PermianMesozoic rift systems on mountain building. Tectonophysics 764 : $25-45$.

Fabriès J, Lorand J-P, Bodinier J-L, Dupuy C. 1991. Evolution of the Upper Mantle beneath the Pyrenees: Evidence from Orogenic Spinel Lherzolite Massifs. Journal of Petrology Special-Volume 55-76.

Fabriès J, Lorand J-P, Bodinier J-L. 1998. Petrogenetic evolution of orogenic lherzolite massifs in the central and western Pyrenees. Tectonophysics 292: 145-167.

Fitzgerald PG, Muñoz JA, Coney PJ, Baldwin SL. 1999. Asymmetric exhumation across the Pyrenean orogen: Implications for the tectonic evolution of a collisional orogen. Earth and Planetary Science Letters 173(3): 157-170.

Fillon C, van der Beek P. 2012. Post-orogenic evolution of the southern Pyrenees: Constraints from inverse thermo-kinematic modelling of low-temperature thermochronology data. Basin Research 24(4): 418-436.

Fillon C, Mouthereau F, Calassou S, Pik R, Bellahsen N, Gautheron C, et al. 2021. Post-orogenic exhumation in the western Pyrenees: Evidence for extension driven by preorogenic inheritance. Geological Society, London. https://doi. org/10.1144/jgs2020-079.

Ford M, Hemmer L, Vacherat A, Gallagher K, Christophoul F. 2016. Retro-wedge foreland basin evolution along the ECORS line, eastern Pyrenees, France. Journal of the Geological Society 173(3): 419-437.

Garrido M, Megias G. 1972. Sintesis geologica del secundario y terciario entre los rios cinca y segre. (pirineo central de la vertiente sur pirenaica, provincias de huesca y lerida). Bol. Geol. Min. 83: 1-47.

García Senz J. 2002. Cuencas extensivas del Cretácico Inferior en los Pirineos centrales. Formación y subsecuente inversión. Universitat de Barcelona.

Golberg JM, Leyreloup AF. 1990. High temperature-low pressure Cretaceous metamorphism related to crustal thinning (Eastern North Pyrenean Zone, France). Contributions to Mineralogy and Petrology 104: 194-207.

Goldstein RH. 2001. Fluid inclusions in sedimentary and diagenetic systems. Lithos 55(1-4): 159-193.

Gómez-Romeu J, Masini E, Tugend J, Ducoux M, Kusznir N. 2019. Role of rift structural inheritance in orogeny highlighted by the Western Pyrenees case-study. Tectonophysics 766: 131-150.

Grare A, Lacombe O, Mercadier J, Benedicto A, Guilcher M, Trave A, et al. 2018. Fault zone evolution and development of a structural and hydrological barrier: the quartz breccia in the Kiggavik Area (Nunavut, Canada) and its control on uranium mineralization. Minerals 8(8): 319.

Incerpi N, Manatschal G, Martire L, Bernasconi SM, Gerdes A, Bertok C. 2020. Characteristics and timing of hydrothermal fluid circulation in the fossil Pyrenean hyperextended rift system: new constraints from the Chaînons Béarnais (W Pyrenees). International Journal of Earth Sciences 109(3): 1071-1093.

Jammes S, Manatschal G, Lavier L, Masini E. 2009. Tectonosedimentary evolution related to extreme crustal thinning ahead of a propagating ocean: Example of the western Pyrenees. Tectonics 28 (4): TC4012. https://doi.org/10.1029/2008TC002406.

Jourdon A, Le Pourhiet L, Mouthereau F, Masini E. 2019. Role of rift maturity on the architecture and shortening distribution in mountain belts. Earth and Planetary Science Letters 512: 89-99.

Labaume P, Teixell A. 2020. Evolution of salt structures of the Pyrenean rift (Chaînons Béarnais, France): From hyper-extension to tectonic inversion. Tectonophysics 785: 228451.

Lacrampe G. 1990. Origine des gaz d'Aquitaine sud, Rapport de phase 1, Compilation des données disponibles proposition de travaux complémentaires. TOTAL EP Internal Report.

Lacroix B, Travé A, Buatier M, Labaume P, Vennemann T, Dubois M. 2014. Syntectonic fluid-flow along thrust faults: Example of the South-Pyrenean fold-and-thrust belt. Marine and Petroleum Geology 49: 84-98.

Lagabrielle Y, Bodinier JL. 2008. Submarine reworking of exhumed subcontinental mantle rocks: field evidence from the Lherz peridotites, French Pyrenees. Terra Nova 20(1): 11-21.

Lagabrielle Y, Labaume P, de Saint Blanquat M. 2010. Mantle exhumation, crustal denudation, and gravity tectonics during Cretaceous rifting in the Pyrenean realm (SW Europe): Insights from the geological setting of the lherzolite bodies. Tectonics 29(4).

Lescoutre R, Tugend J, Brune S, Masini E, Manatschal G. 2019. Thermal evolution of asymmetric hyperextended magma-poor rift systems: results from numerical modelling and Pyrenean field observations. Geochemistry, Geophysics, Geosystems 20(10): 4567-4587.

Louis S, Luijendijk E, Dunk1 I, Person M. 2019. Episodic fluid flow in an active fault. Geology 47(10): 938-942.

Macchiavelli C, Vergés J, Schettino A, Fernàndez M, Turco E, Casciello E, et al. 2017. A new southern North Atlantic isochron map: Insights into the drift of the Iberian plate since the Late 
Cretaceous. Journal of Geophysical Research: Solid Earth 122 (12): 9603-9626.

Magee ME, Zoback MD. 1993. Evidence for a weak interplate thrust fault along the northern Japan subduction zone and implications for the mechanics of thrust faulting and fluid expulsion. Geology 21(9): 809-812.

Martín-Chivelet J, Floquet M, García Senz J, Callapez PM, LópezMir B, Muñoz JA, et al. 2019. Late Cretaceous Post-Rift to Convergence in Iberia. In: The Geology of Iberia: A Geodynamic Approach. Cham: Springer, pp. 285-376.

Masini E, Manatschal G, Tugend J, Mohn G, Flament JM. 2014. The tectono-sedimentary evolution of a hyper-extended rift basin: The example of the Arzacq-Mauléon rift system (Western Pyrenees, SW France). International Journal of Earth Sciences 103(6): 1569-1596.

Mattauer M, Proust F. 1962. Sur la tectonique de la fin du Crétacé et du début du Tertiaire en Languedoc. Rev. Géogr: Phys. Géol. Dyn. V: 5-21.

McCaig AM. 1988. Deep fluid circulation in fault zones. Geology 16 (10): 867-870.

McCaig AM, Tritlla J, Banks DA. 2000. Fluid flow patterns during Pyrenean thrusting. Journal of Geochemical Exploration 69: 539-543.

McClay K, Munoz J-A, Garcia Senz J. 2004. Extensional salt tectonics in a contractional orogen: A newly identified tectonic event in the Spanish Pyrenees. Geology 32: 737-740.

Milesi G, Soliva R, Monié P, Münch P, Bellanger M, Bruguier O, et al. 2019. Mapping a geothermal anomaly using apatite (U-Th)/He thermochronology in the Têt fault damage zone, eastern Pyrenees, France. Terra Nova 31(6): 569-576.

Milesi G, Monié P, Münch P, Soliva R, Taillefer A, Bruguier O, et al. 2020. Tracking geothermal anomalies along a crustal fault using (U-Th)/He apatite thermochronology and rare-earth element (REE) analyses: The example of the Têt fault (Pyrenees, France). Solid Earth 11(5): 1747-1771.

Milkov AV, Etiope G. 2018. Revised genetic diagrams for natural gases based on a global dataset of $>20000$ samples. Organic Geochemistry 125: 109-120.

Motte G, Hoareau G, Callot JP, Révillon S, Piccoli F, Calassou S, Gaucher EC. 2021. Rift and salt-related multi-phased dolomitization: example from the northwestern Pyrenees. Marine and Petroleum Geology 126: 104932.

Mouthereau F, Filleaudeau PY, Vacherat A, Pik R, Lacombe O, Fellin MG, et al. 2014. Placing limits to shortening evolution in the Pyrenees: Role of margin architecture and implications for the Iberia/Europe convergence. Tectonics 33(12): 2283-2314.

Muñoz JA. 1992. Evolution of a continental collision belt: ECORSPyrenees crustal balanced cross-section. In: Thrust tectonics. Dordrecht: Springer, pp. 235-246..

Oliva-Urcia B, Beamud E, Arenas C, Pueyo EL, Garcés M, Soto R, et al. 2019. Dating the northern deposits of the Ebro foreland basin; implications for the kinematics of the SW Pyrenean front. Tectonophysics 765: 11-34.

Olivet JL. 1996. La cinématique de la plaque ibérique. Bulletin des centres de recherches exploration-production Elf-Aquitaine 20(1): 131-195.

Ortiz A, Guillocheau F, Lasseur E, Briais J, Robin C, Serrano O, Fillon C. 2020. Sediment routing system and sink preservation during the post-orogenic evolution of a retro-foreland basin: The case example of the North Pyrenean (Aquitaine, Bay of Biscay) Basins. Marine and Petroleum Geology 112: 104085.
Quesnel B, Boiron MC, Cathelineau M, Truche L, Rigaudier T, Bardoux G, et al. 2019. Nature and origin of mineralizing fluids in hyperextensional systems: The case of cretaceous $\mathrm{Mg}$ metasomatism in the Pyrenees. Geofluids 2019. https://doi.org/10.1155/2019/ 7213050 .

Ravier J. 1959. Le metamorphisme des terrains secondaires des Pyrénées. Mem. Soc. Geol. Fr. Nouv. Ser., Vol.38. Paris : Société géologique de France.

Renard S, Pironon J, Sterpenich J, Carpentier C, Lescanne M, Gaucher EC. 2019. Diagenesis in Mesozoic carbonate rocks in the North Pyrénées (France) from mineralogy and fluid inclusion analysis: Example of Rousse reservoir and caprock. Chemical Geology 508: 30-46.

Rocher M, Lacombe O, Angelier J, Deffontaines B, Verdier F. 2000. Cenozoic folding and faulting in the south Aquitaine Basin (France): insights from combined structural and paleostress analyses. Journal of Structural Geology 22(5): 627-645.

Roest WR, Srivastava SP. 1991. Kinematics of the plate boundaries between Eurasia, Iberia, and Africa in the North Atlantic from the Late Cretaceous to the present. Geology 19(6): 613-616.

Rosenbaum G, Lister GS, Duboz C. 2002. Relative motions of Africa, Iberia and Europe during Alpine orogeny. Tectonophysics 359 (1-2): 117-129.

Rye DM, Bradbury HJ. 1988. Fluid flow in the crust: An example from a Pyrenean thrust ramp. American Journal of Science 288(3): 197-235.

Salardon R, Carpentier C, Bellahsen N, Pironon J, France-Lanord C. 2017. Interactions between tectonics and fluid circulations in an inverted hyper-extended basin: Example of mesozoic carbonate rocks of the western North Pyrenean Zone (Chaînons Béarnais, France). Marine and Petroleum Geology 80: 563-586.

Sibson RH. 1981. Fluid flow accompanying faulting: Field evidence and models. Earthquake Prediction: An International Review 4: 593-603.

Sibson RH. 2000. Fluid involvement in normal faulting. Journal of Geodynamics 29(3-5): 469-499.

Sibuet JC, Srivastava SP, Spakman W. 2004. Pyrenean orogeny and plate kinematics. Journal of Geophysical Research: Solid Earth 109(B8).

Smeraglia L, Fabbri O, Choulet F, Buatier M, Boulvais P, Bernasconi SM, et al. 2020. Syntectonic fluid flow and deformation mechanisms within the frontal thrust of a foreland fold-and-thrust belt: Example from the Internal Jura, Eastern France. Tectonophysics 778: 228178.

Teixell A. 1998. Crustal structure and orogenic material budget in the west central Pyrenees. Tectonics 17(3): 395-406.

Teixell A, Labaume P, Lagabrielle Y. 2016. The crustal evolution of the west-central Pyrenees revisited: Inferences from a new kinematic scenario. Comptes Rendus Geoscience 348(3-4): 257-267.

Ternois S, Odlum M, Ford M, Pik R, Stockli D, Tibari B, et al. 2019. Thermochronological evidence of early orogenesis, eastern Pyrenees, France. Tectonics 38(4): 1308-1336.

Thinon I, Fidalgo-González L, Réhault JP, Olivet JL. 2001. Déformations pyrénéennes dans le golfe de Gascogne. Comptes Rendus de l'Académie des Sciences-Series IIA-Earth and Planetary Science 332(9): 561-568.

Travé A, Labaume P, Calvet F, Soler A. 1997. Sediment dewatering and pore fluid migration along thrust faults in a foreland basin inferred from isotopic and elemental geochemical analyses (Eocene southern Pyrenees, Spain). Tectonophysics 282(1-4): 375-398. 
Travé A, Labaume P, Calvet F, Soler A, Tritlla J, Buatier M, et al. 1998. Fluid migration during Eocene thrust emplacement in the south Pyrenean Foreland Basin (Spain): An integrated structural, mineralogical and geochemical approach. Geological Society, London, Special Publications 134(1): 163-188.

Travé A, Calvet F, Sans M, Vergés J, Thirlwall M. 2000. Fluid history related to the Alpine compression at the margin of the south-Pyrenean Foreland Basin: the El Guix anticline. Tectonophysics 321(1): 73-102.

Travé A, Labaume P, Vergés J. 2007. Fluid systems in foreland foldand-thrust belts: An overview from the Southern Pyrenees. In: Thrust Belts and Foreland Basins. Berlin, Heidelberg: Springer, pp. 93-115.

Tugend J, Manatschal G, Kusznir NJ, Masini E, Mohn G, Thinon I. 2014. Formation and deformation of hyperextended rift systems: Insights from rift domain mapping in the Bay of Biscay-Pyrenees. Tectonics 33(7): 1239-1276.

Vacherat A, Mouthereau F, Pik R, Bernet M, Gautheron C, Masini E, et al. 2014. Thermal imprint of rift-related processes in orogens as recorded in the Pyrenees. Earth and Planetary Science Letters 408: 296-306.

Van den Kerkhof AM, Hein UF. 2001. Fluid inclusion petrography. Lithos 55(1-4): 27-47.
Vergés J, García Senz J. 2001. Mesozoic evolution and Cainozoic inversion of the Pyrenean rift. Mémoires du Muséum national d'histoire naturelle (1993) 186: 187-212.

Vergés J, Millán H, Roca E, Muñoz JA, Marzo M, Cirés J, et al. 1995. Eastern Pyrenees and related foreland basins: Pre-, syn-and postcollisional crustal-scale cross-sections. Marine and Petroleum Geology 12(8): 903-915.

Vergés J, Fernàndez M, Martínez A. 2002. The Pyrenean orogen: Pre-, syn-, and post-collisional evolution. Journal of the Virtual Explorer 8: $55-74$.

Waldner M, Bellahsen N, Mouthereau F, Bernet M, Pik R, Rosenberg CL, et al. 2021. Central Pyrenees mountain building: Constraints from new LT thermochronological data from the Axial Zone. Tectonics 40: e2020TC006614.

Weis P, Driesner T, Heinrich CA. 2012. Porphyry-copper ore shells form at stable pressure-temperature fronts within dynamic fluid plumes. Science 338(6114): 1613-1616.

Whitchurch AL, Carter A, Sinclair HD, Duller RA, Whittaker AC, Allen PA. 2011. Sediment routing system evolution within a diachronously uplifting orogen: Insights from detrital zircon thermochronological analyses from the South-Central Pyrenees. American Journal of Science 311(5): 442-482.

Yardley BWD, Graham JT. 2002. The origins of salinity in metamorphic fluids. Geofluids 2(4): 249-256.

Cite this article as: Barré G, Fillon C, Ducoux M, Mouthereau F, Gaucher EC, Calassou S. 2021. The North Pyrenean Frontal Thrust: structure, timing and late fluid circulation inferred from seismic and thermal-geochemical analyses of well data, BSGF - Earth Sciences Bulletin 192: 52. 